University of Nebraska - Lincoln

DigitalCommons@University of Nebraska - Lincoln

2006

\title{
Unusual Holocene and late Pleistocene carbonate sedimentation in Bear Lake, Utah and Idaho, USA
}

Walter E. Dean

U.S. Geological Survey, Denver, CO, dean@usgs.gov

Joseph Rosenbaum

U.S. Geological Survey, Federal Center, Denver, Colorado, USA

Gary Skipp

U.S. Geological Survey, gskipp@usgs.gov

Steven Colman

Large Lakes Observatory, University of Minnesota, Duluth, MN 02543, USA

Richard Forester

U.S. Geological Survey, Federal Center, Denver, Colorado, USA

See next page for additional authors

Follow this and additional works at: https://digitalcommons.unl.edu/usgsstaffpub

Part of the Earth Sciences Commons

Dean, Walter E.; Rosenbaum, Joseph; Skipp, Gary; Colman, Steven; Forester, Richard; Liu, An; Simmons, Kathleen R.; and Bischoff, James, "Unusual Holocene and late Pleistocene carbonate sedimentation in Bear Lake, Utah and Idaho, USA" (2006). USGS Staff -- Published Research. 314.

https://digitalcommons.unl.edu/usgsstaffpub/314

This Article is brought to you for free and open access by the US Geological Survey at DigitalCommons@University of Nebraska - Lincoln. It has been accepted for inclusion in USGS Staff -- Published Research by an authorized administrator of DigitalCommons@University of Nebraska - Lincoln. 


\section{Authors}

Walter E. Dean, Joseph Rosenbaum, Gary Skipp, Steven Colman, Richard Forester, An Liu, Kathleen R. Simmons, and James Bischoff 


\title{
Unusual Holocene and late Pleistocene carbonate sedimentation in Bear Lake, Utah and Idaho, USA
}

\author{
Walter Dean ${ }^{\text {a,* }}$, Joseph Rosenbaum ${ }^{\text {a }}$, Gary Skipp ${ }^{\text {a }}$, Steven Colman ${ }^{\text {b }}$, Richard Forester ${ }^{\text {a }}$, \\ An Liu ${ }^{c}$, Kathleen Simmons ${ }^{\text {a, James Bischoff }}{ }^{\mathrm{d}}$ \\ ${ }^{a}$ U.S. Geological Survey, Federal Center, Denver, Colorado, USA \\ ${ }^{\mathrm{b}}$ Large Lakes Observatory, University of Minnesota, Duluth, MN 02543, USA \\ c University of Minnesota, St. Paul, MN 55108, USA \\ ${ }^{d}$ U.S. Geological Survey, 345 Middlefield Rd., Menlo Park, CA 94025, USA
}

\begin{abstract}
Bear Lake (Utah-Idaho, USA) has been producing large quantities of carbonate minerals of varying mineralogy for the past 17,000 years. The history of sedimentation in Bear Lake is documented through the study of isotopic ratios of oxygen, carbon, and strontium, percent organic carbon, percent $\mathrm{CaCO}_{3}, \mathrm{X}$-ray diffraction mineralogy, HCl-leach inorganic geochemistry, and magnetic properties on samples from three piston cores. Historically, the Bear River, the main source of water for Great Salt Lake, did not enter Bear Lake until it was artificially diverted into the lake at the beginning of the 20th century. However, during the last glacial interval, the Bear River did enter Bear Lake depositing red, calcareous, silty clay. About 18,000 years ago, the Bear River became disconnected from Bear Lake. A combination of warmer water, increased evaporation, and increased organic productivity triggered the precipitation of calcium carbonate, first as calcite. As the salinity of the lake increased due to evaporation, aragonite began to precipitate about 11,000 years ago. Aragonite is the dominant mineral that accumulated in bottom sediments of the lake during the Holocene, comprising an average of about $70 \mathrm{wt} \%$ of the sediments. Aragonite formation in a large, cold, oligotrophic, high latitude lake is highly unusual. Lacustrine aragonite usually is found in small, saline lakes in which the salinity varies considerably over time. However, Bear Lake contains endemic ostracodes and fish, which indicate that the chemistry of the lake has remained fairly constant for a long time. Stable isotope data from Holocene aragonite show that the salinity of Bear Lake increased throughout the Holocene, but never reached highly evolved values of $\delta^{18} \mathrm{O}$ in spite of an evaporation-dominated water balance. Bear Lake hydrology combined with evaporation created an unusual situation that produced large amounts of aragonite, but no evaporite minerals.
\end{abstract}

Published by Elsevier B.V.

Keywords: Calcite; Aragonite; Organic carbon; Oxygen, carbon, and strontium isotopes; Leach chemistry

\footnotetext{
* Corresponding author. Tel.: +1 303236 5760; fax: +1 303236 5349.

E-mail address: dean@usgs.gov (W. Dean).
}

\section{Introduction}

Bear Lake is an oligotrophic, mesosaline lake in northeastern Utah and adjacent Idaho (Fig. 1) that presently occupies the southern end of the Bear Lake Valley, which is formed by a half graben (Colman, 2005). The lake is $32 \mathrm{~km}$ long and $6-13 \mathrm{~km}$ wide 


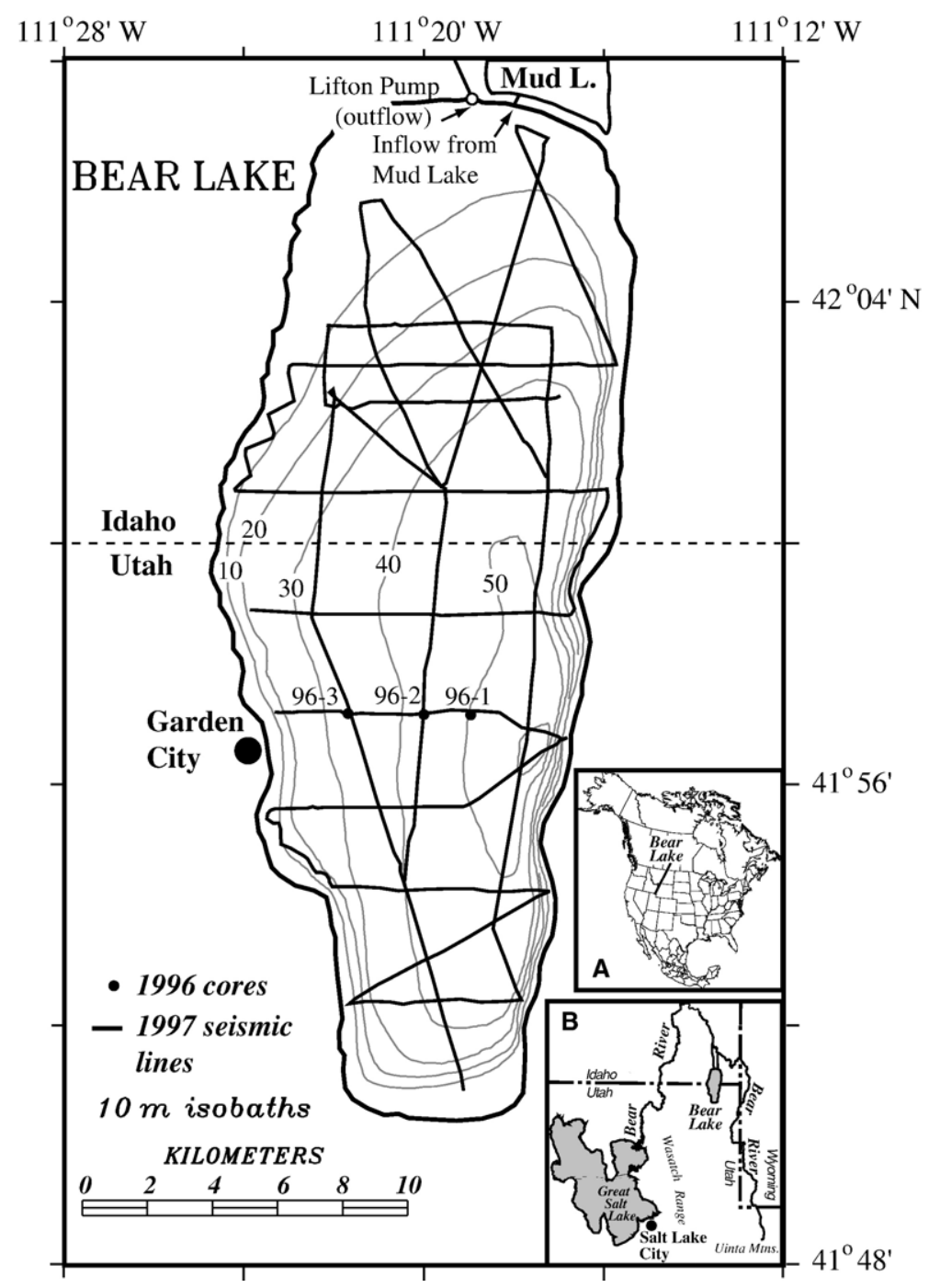

Fig. 1. Bathymetric map of Bear Lake Utah-Idaho, showing the locations of 1996 piston cores and 1997 acoustic-reflection lines. Inset A shows the location of Bear Lake within North Amertica. Inset B shows the location of Bear Lake relative to Bear River and Great Salt Lake.

with an area of $280 \mathrm{~km}^{2}$ at full capacity. Maximum depth is $63 \mathrm{~m}$, with a mean depth of $28 \mathrm{~m}$ (Birdsey, 1989). The present elevation of the lake is $1805 \mathrm{~m}$ above sea level (mbsl) when full, but this level may have varied considerably through time with highstands of perhaps $11 \mathrm{~m}$ above the present level (Laabs and Kaufman, 2003). Historic low lake levels occurred during the 1930s and in 2004. Post-depositional uplift in this tectonically active valley hampers an accurate reconstruction of water levels in the valley. The natural watershed of the lake is relatively small, with a basinarea:lake-area ratio of only 4.8:1 (Wurtsbaugh and Luecke, 1997). Historically, the Bear River has not flowed into Bear Lake, but a part of its flow was diverted into Bear Lake through a series of canals, beginning in 1909 with completion in 1918 (Birdsey, 1989), making Bear Lake a reservoir to supply irrigation water and hydroelectric power downstream. The diversion inflow increased the basin-area:lake-area ratio considerably to $29.5: 1$.

Acoustic-reflection $(3.5 \mathrm{kHz})$ profiles obtained in 1997 and chirp (4-24 kHz) acoustic profiles and sidescan sonar data obtained in 2002 (Colman, 2005) indicate that the principal structure of the basin is a half graben, with a steep normal-fault margin on the east and a ramp margin on the west (Fig. 2). Acoustic reflectors diverge toward the master fault, forming eastward thickening sediment wedges, so that sedimentary units pinch out to the west. Acoustic profiles indicate that Holocene sediments are thin or missing 


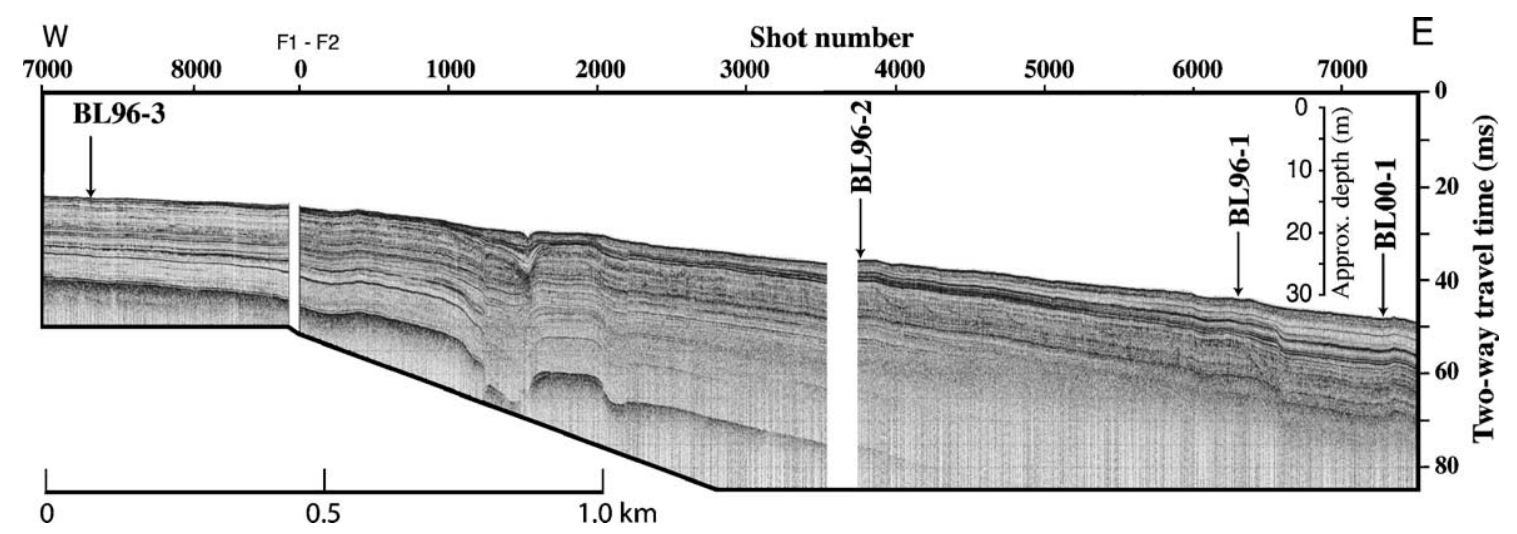

Fig. 2. Interpreted 2002 chirp acoustic-reflection profile across Bear Lake showing the locations of 1996 piston cores (Fig. 1; Colman, 2005). The location of the chirp line is approximately the same as the1997 acoustic-reflection line west of Garden City, Utah in Fig. 1 showing the locations of the three cores.

in water depths shallower than about $30 \mathrm{~m}$, but the deepest part of the lake contains at least several hundred meters of sediment, and the basin could be as much as six million years old (Colman, 2005). Acoustic profiles and other observations further indicate that there is reworking and redistribution of sediment from shallow sites to deeper sites (focusing) in Bear Lake (Colman, 2005). The presence of shallow-water diatoms in some horizons indicates some sediment transport from the lake margins to the center (Smoot, 2005).

The purpose of this paper is to examine the glacial to Holocene evolution of sedimentation in Bear Lake. In particular, why is aragonite the dominant carbonate mineral that formed during the Holocene in this large, cold, deep, oligotrophic, high latitude, montane lake?

\section{Materials and methods}

Piston cores were collected in 1996 from three localities in Bear Lake (Fig. 1) using the University of Minnesota, Limnological Research Center's Kullenberg coring system. Core BL96-1 is $5 \mathrm{~m}$ long from a water depth of $50 \mathrm{~m}$. Core BL96-2 is $4 \mathrm{~m}$ long from a water depth of $40 \mathrm{~m}$. Core BL96-3 is $4 \mathrm{~m}$ long from a water depth of $30 \mathrm{~m}$. The three cores provide a composite section that records geochemical proxies of climate and environmental change over more than 30,000 years. The Holocene sediments are carbonate-rich (predominantly aragonite), and the glacial-age sediments consist of calcareous silty clay.

Representative detrital material from throughout the catchment was obtained by sampling alluvial sediment from sites along streams in the local Bear Lake catchment and along Bear River above Bear Lake (Fig. 3). Samples were subdivided by sieving into four grain-

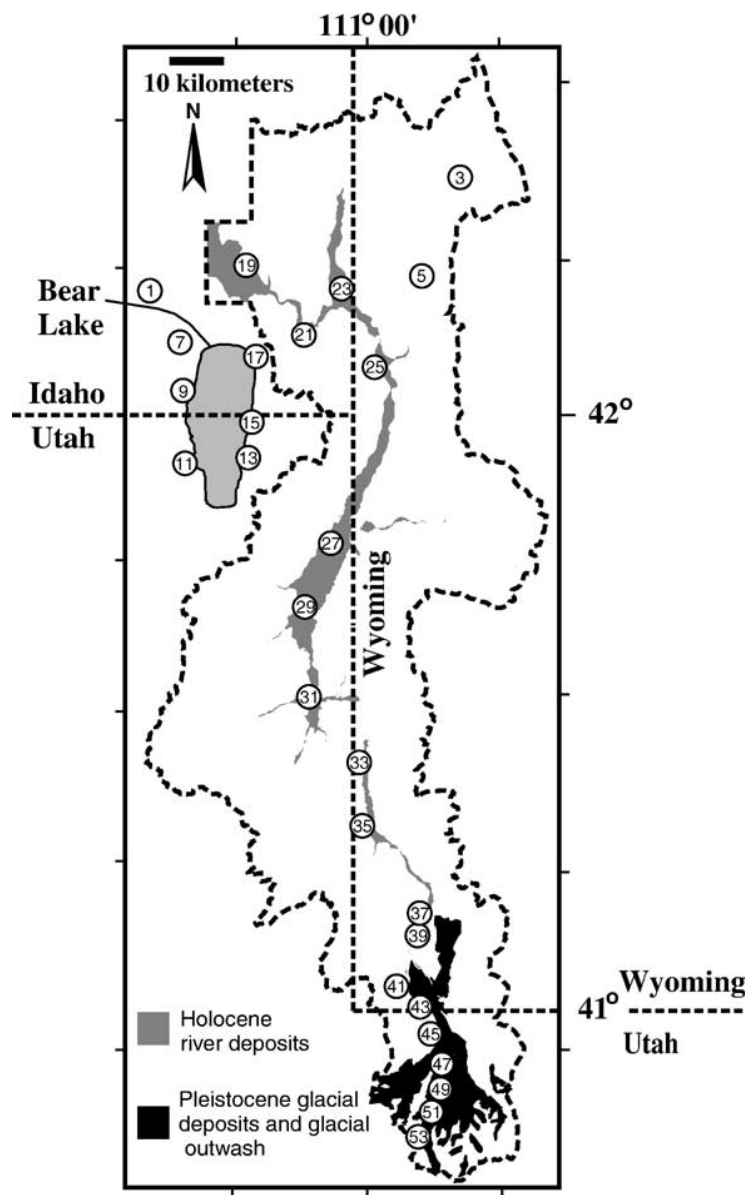

Fig. 3. Locations of stream-sediment samples. Odd and even numbered samples were collected at each site, but only the odd numbers are shown. Odd numbered samples were taken from the stream bottoms; even numbered samples were from stream-bank or overbank deposits. 
size fractions: pebbles, coarse sand and granules, fine and medium sand, and silt plus clay $(<63 \mu \mathrm{m})$.

Each of the three cores from the lake was cut into 1$\mathrm{m}$-long sections, and each section was sectioned longitudinally into a working half and an archive half. The working half of each section was cut into 1-cm-thick slabs for analyses. Most of the analyses described below were performed on every fourth $1-\mathrm{cm}$ sample (e.g., 0-1 cm, 4-5 cm, 8-9 cm, etc.). Exceptions to this analytical scheme are noted.

Concentrations of total carbon (TC) and inorganic carbon (IC) in samples from the three piston cores were determined by coulometric titration of $\mathrm{CO}_{2}$ following extraction from the sediment by combustion at $950{ }^{\circ} \mathrm{C}$ and acid volatilization, respectively (Engleman et al., 1985), in USGS laboratories, Denver, CO. Weight percent IC was converted to weight percent $\mathrm{CaCO}_{3}$ by dividing by 0.12 , the fraction of carbon in $\mathrm{CaCO}_{3}$. Organic carbon (OC) was determined by difference between TC and IC.

Semi-quantitative estimates of mineral contents in splits of the carbon samples and in the silt plus clay fractions of stream-sediment samples were determined by standard X-ray diffraction (XRD) techniques (e.g., Moore and Reynolds, 1989) in USGS laboratories, Denver, CO. Each sample was packed into an aluminum holder and scanned from $15^{\circ}$ to $50^{\circ} 2 \Theta$ at $2^{\circ} 2 \Theta /$ min using Ni-filtered, $\mathrm{Cu}-\mathrm{K} \alpha$ radiation at $45 \mathrm{kV}, 30 \mathrm{ma}$, and peak intensities recorded as counts per second (cps). Results are reported as the peak intensity of the main XRD peak (I; in cps) for each mineral, and as a percentage of the sum of the main XRD peak intensities of all minerals. These percentage calculations should be used with caution because they do not reflect the different X-ray mass absorption characteristics of different minerals. More quantitative estimates of aragonite and low-Mg calcite, the dominant minerals deposited over the last 18,000 years, were calculated by partitioning the percentage of total $\mathrm{CaCO}_{3}$, determined by coulometry, using the intensity ratio of the main XRD peak of aragonite to that of low-Mg calcite $(I-A / I-C)$, and curves of percent aragonite (of total $\mathrm{CaCO}_{3}$ ) versus $I-$ $A / I-C$ as determined by Chave (1954) and Lowenstam (1954). The curve of Lowenstam (1954) is closely represented by the equation

$$
\begin{aligned}
\% \text { aragonite }= & -4.4992+[105.3188 \\
& \times(I-A / I-C)] /[0.2362 \\
& +(I-A / I-C)] .
\end{aligned}
$$

Measurements of ratios of stable isotopes of carbon and oxygen were made in the isotope laboratory in the
Department of Geology and Geophysics, University of Minnesota. Samples were reacted with $100 \%$ anhydrous phosphoric acid at $75 \pm 1{ }^{\circ} \mathrm{C}$. Evolved gases were cryogenically purified to remove water and noncondensible gases. The purified $\mathrm{CO}_{2}$ was introduced into an isotope-ratio mass spectrometer through a capillary, and isotopic ratios of carbon and oxygen were measured against a reference standard of known isotopic composition. Carbon- and oxygen-isotope measurements on the silt plus clay fractions of seven streamsediment samples were made in the isotope laboratory at the University of Arizona. Results of all analyses are reported in the standard per mil (\%o) $\delta$-notation relative to the Vienna Pee Dee Belemnite (VPDB) marine-carbonate standard for carbon and oxygen:

$\delta \%_{0}=\left[\left(R_{\text {sample }} / R_{\mathrm{VPDB}}\right)-1\right] \times 10^{3}$

where $R$ is the ratio $\left({ }^{13} \mathrm{C}:{ }^{12} \mathrm{C}\right)$ or $\left({ }^{18} \mathrm{O}:{ }^{16} \mathrm{O}\right)$.

Measurements of $\mathrm{Sr}$ isotope ratios were made on samples from core 96-2, and silt plus clay fractions of stream-sediment samples, in USGS laboratories in Denver, CO. Samples were leached in $5 \mathrm{M}$ acetic acid, and the leachate was centrifuged and purified with conventional ion-exchange methods. Samples were loaded on a single tantalum filament with phosphoric acid. Isotope ratios were measured with an automated VG54 sector multi-collector, thermal ionization mass spectrometer in dynamic mode. Mass dependent fractionation was corrected assuming a ${ }^{86} \mathrm{Sr} /{ }^{87} \mathrm{Sr}$ ratio of 0.1194 . Strontium isotope ratios are reported relative to SRM-987 standard value of 0.71025 .

The silt plus clay fractions of stream-sediment samples were analyzed for 40 major, minor, and trace elements by inductively coupled, argon-plasma, atomic-emission spectrometry (ICP-AES) by XRAL Laboratories, Toronto, Canada. Rock standards (USGS) were included with the sediment samples, and 10\% of the samples were duplicated. The precision, determined by analyzing rock standards and duplicate sediment samples, is better than $10 \%$, and usually is better than $5 \%$, at a concentration of 10 times the limit of detection.

Analyses of acid-soluble elements were conducted in USGS laboratories in Menlo Park, CA. Samples were leached in $3 \mathrm{~N} \mathrm{HCl}$ overnight, and the supernatant was analyzed by inductively coupled, argon-plasma, atomic-emission spectrometry (ICP-AES) for major components (percent) $\mathrm{Ca}, \mathrm{Fe}$, and $\mathrm{Mg}$, and minor components (parts per million, ppm) $\mathrm{Mn}, \mathrm{Ba}$, and $\mathrm{Sr}$ (Bischoff et al., 2005). 
Wet sediment from every other 1-cm sample from core 96-2, and the silt plus clay fraction of streamsediment samples, was placed in a nonmagnetic 3.2 $\mathrm{cm}^{3}$ plastic box for measurements of magnetic properties. Hard isothermal remanent magnetization (HIRM; see King and Channel, 1991) was determined on samples from core 96-2 and on fluvial samples from throughout the catchment (Fig. 3). Isothermal remnant magnetization was first imparted in a field of $1.2 \mathrm{~T}$ $\left(\mathrm{IRM}_{1.2 \mathrm{~T}}\right)$, and measured with a high-speed spinner magnetometer. A second IRM was then imparted in the opposite direction in a field of $0.3 \mathrm{~T}\left(\mathrm{IRM}_{0.3 \mathrm{~T}}\right)$. HIRM, calculated as $\left(\mathrm{IRM}_{1.2 \mathrm{~T}}-\mathrm{IRM}_{0.3 \mathrm{~T}}\right) / 2$, largely reflects the content of high-coercivity minerals such as hematite and greigite.

Accelerator mass spectrometer (AMS) ${ }^{14} \mathrm{C}$ ages were obtained from samples of various materials including pollen concentrates, ostracodes, and bulk-sediment OC (Colman et al., 2005; Table 1). The "pollen" samples were prepared using standard palynological methods and contain some charcoal and other refractory organic matter. Reservoir corrections were made for AMS dates on bulk OC by subtracting 480 years from the raw dates, and by subtracting 370 years from dates on ostracodes (Colman et al., 2005). Reservoir-corrected and calibrated radiocarbon ages are expressed in kiloannum BP (e.g., 26.6 cal ka). Raw and calibrated radiocarbon ages for each of the three cores are given in Table 1.

\section{Results}

\subsection{The cores}

Each of the Kullenberg piston cores collected in 1996 penetrated a maximum of $5 \mathrm{~m}$. The collected sediments were deposited over the last $31 \mathrm{cal} \mathrm{ka,} \mathrm{well}$ beyond the last glacial maximum (LGM; ca. 21 cal ka). As seen in Fig. 2, the sedimentary sequence in Bear Lake consists of a series of eastward dipping strata the shallowest of which pinch out to the west. Therefore, the three cores (96-1, 96-2, and 96-3, Fig. 1) contain overlapping sequences. This can be seen in the acoustic profiles in Fig. 2, and in the profiles of calcite and aragonite versus depth shown in Fig. 4. The upper aragonite-dominated sequence, which was deposited over the last $7 \mathrm{ky}$, is present throughout the $500 \mathrm{~cm}$ of section in core $96-1$, and in the upper 170 $\mathrm{cm}$ in core $96-2$. Based on ${ }^{14} \mathrm{C}$ ages, the bottom of core 96-1 just missed the top of the calcite-dominated sequence that occurs at $170-200 \mathrm{~cm}$ in core 96-2. This calcite layer in core 96-2 overlies a lower ara-
Table 1

Radiocarbon ages on materials separated from sediment samples from cores BL-96-1, BL-96-2, and BL96-3

\begin{tabular}{|c|c|c|c|c|c|}
\hline Core ID & $\begin{array}{l}\text { Depth } \\
\text { (cmblf) }\end{array}$ & Material & $\begin{array}{l}{ }^{14} \mathrm{C} \text { age } \\
\text { (years) }\end{array}$ & $\begin{array}{l}\text { Error } \\
\text { (years) }\end{array}$ & $\begin{array}{l}\text { Calib. age } \\
\text { (cal year BP) }\end{array}$ \\
\hline \multicolumn{6}{|l|}{ BL96-1 } \\
\hline $1-\mathrm{A}-52$ & 48 & Pollen & 1070 & 40 & 970 \\
\hline $1-\mathrm{C}-55$ & 252 & Pollen & 3320 & 40 & 3545 \\
\hline $1-E-3$ & 401 & Pollen & 5260 & 40 & 6055 \\
\hline 1-E-95 & 493 & Bulk (TOC) & 6740 & 50 & 7555 \\
\hline \multicolumn{6}{|l|}{ BL96-2 } \\
\hline $2-A-13$ & 3 & Bulk (TOC) & 1620 & 50 & 1480 \\
\hline $2-B-9$ & 99 & Pollen & 3435 & 60 & 3690 \\
\hline 2-B-31 & 121 & Ostracodes & 4620 & 60 & 5320 \\
\hline 2-B-31 & 121 & Pollen & 4230 & 40 & 4830 \\
\hline 2-B-61 & 151 & Ostracodes & 5460 & 50 & 6280 \\
\hline $2-B-61$ & 151 & Pollen & 5260 & 40 & 5990 \\
\hline $2-B-73$ & 163 & Pollen & 5810 & 50 & 6625 \\
\hline 2-B-85 & 175 & Pollen & 6420 & 50 & 7300 \\
\hline $2-B-85$ & 175 & Bulk (TOC) & 6970 & 50 & 7775 \\
\hline 2-C-10 & 201 & Pollen & 8265 & 70 & 9170 \\
\hline 2-C-21 & 212 & Ostracodes & 9070 & 60 & 10,220 \\
\hline 2-C-21 & 212 & Pollen & 8580 & 40 & 9540 \\
\hline 2-C-55 & 246 & Pollen & 10,300 & 60 & 12,135 \\
\hline 2-D-7 & 299 & Pollen & 12,710 & 50 & 14,960 \\
\hline $2-\mathrm{D}-7$ & 299 & Bulk (TOC) & 13,110 & 60 & 15,605 \\
\hline $2-\mathrm{D}-8$ & 300 & Pollen & 12,545 & 90 & 14,670 \\
\hline 2-D-17 & 307 & Rotifer & 12,400 & 80 & 14,515 \\
\hline 2-D-21 & 313 & Pollen & 14,000 & 100 & 16,790 \\
\hline 2-D-41 & 333 & Pollen & 16,200 & 75 & 19,320 \\
\hline 2-D-61 & 353 & Pollen & 18,550 & 140 & 22,025 \\
\hline 2-D-81 & 373 & Pollen & 21,000 & 110 & 24,750 \\
\hline 2-D-93 & 385 & Pollen & 21,300 & 150 & 25,095 \\
\hline 2-D-101 & 393 & Pollen & 22,600 & 60 & 26,600 \\
\hline \multicolumn{6}{|l|}{$B L-96-3$} \\
\hline $3-A-18$ & 5 & Pollen & 4440 & 40 & 5010 \\
\hline $3-A-33$ & 20 & Pollen & 10,940 & 75 & 12,980 \\
\hline $3-A-46$ & 33 & Pollen & 12,800 & 100 & 15,440 \\
\hline $3-\mathrm{A}-90$ & 77 & Pollen & 19,980 & 60 & 23,670 \\
\hline $3-\mathrm{C}-13$ & 201 & Pollen & 21,850 & 230 & 25,735 \\
\hline $3-\mathrm{C}-89$ & 277 & Pollen & 23,400 & 130 & 27,520 \\
\hline $3-D-89$ & 377 & Pollen & 26,700 & 170 & 31,280 \\
\hline
\end{tabular}

Data from Colman et al. (2005). cmblf $=$ centimeters below lake floor. $\mathrm{TOC}=$ total organic carbon.

gonite-dominated sequence. Core 96-3 contains only a small amount of Holocene sediment. Aragonite that occurs at the top of core 96-3 may correspond to part of the lower aragonite sequence, or it may contain aragonite from both the upper and lower aragonite sequences.

The 400-cm section recovered in core 96-2 contains all of the lithologic units deposited over the last 26,000 cal. year, and appears to be nearly continuous and intact. Therefore, we will focus our attention on that core. A second-order polynomial fit through the cali- 


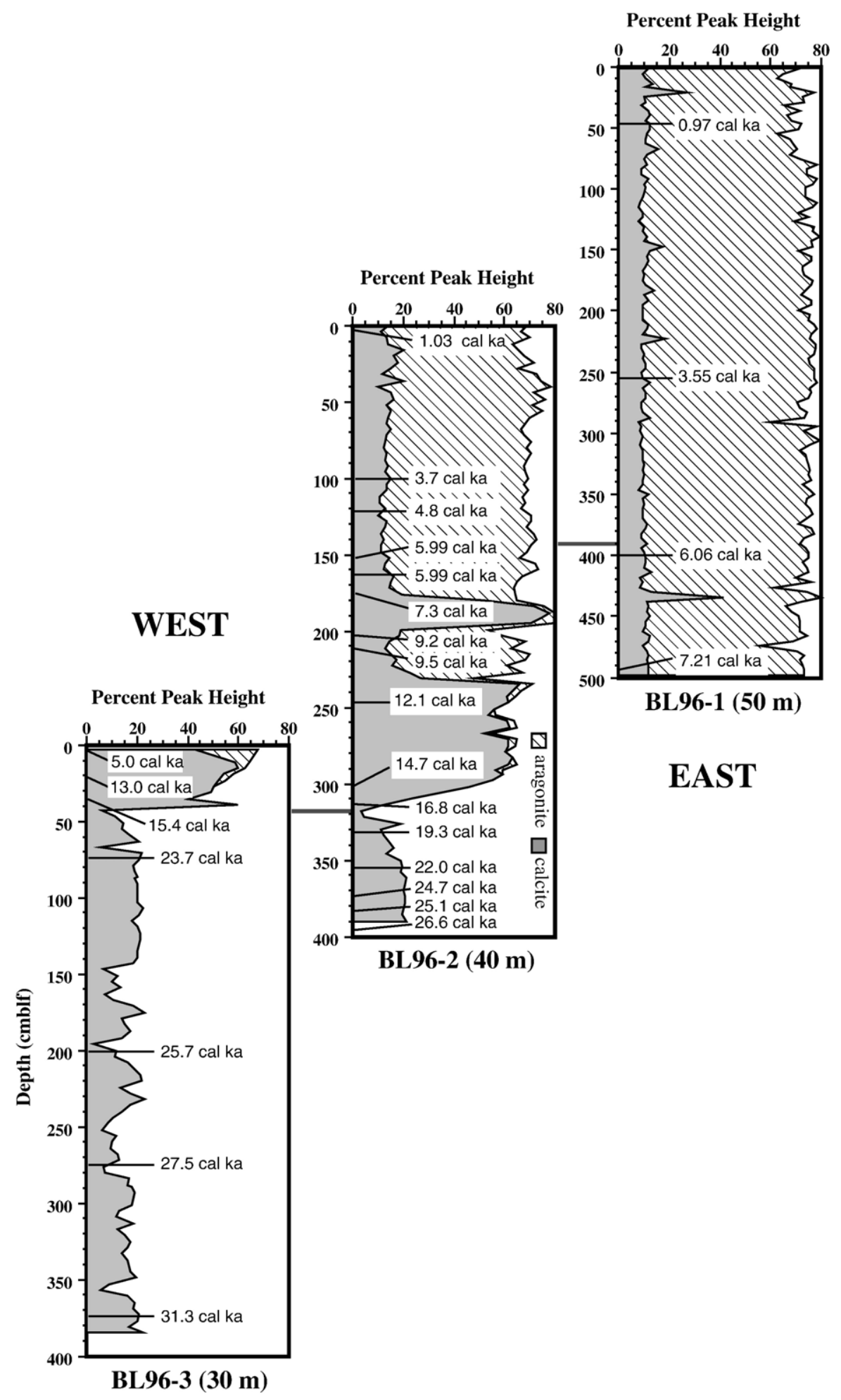

Fig. 4. Profiles of values of $\%$ calcite and $\%$ aragonite (based on XRD peak intensities) in cores 96-1, 96-2, and 96-3 showing correlations between cores based on carbonate mineralogy and radiocarbon ages. Locations of most radiocarbon ages are shown, and all radiocarbon ages are given in Table 1. Core 96-2 appears to contain the entire sequence deposited over the last 26,600 years. 
brated ages of Colman et al. (2005) was used to calculate the ages of all samples. According to the age model, about 900 years of sediment record are missing from the top of core 96-2. This missing time may indicate an unconformity and (or) loss of sediment during coring. Because resuspension and focusing of sediment from shallower to deeper parts of the lake are known to be active processes in Bear Lake (Colman, 2005) hiatuses may exist in the condensed Holocene section in core 96-2 (relative to that in core 96-1). The relatively smooth fit of radiocarbon data versus depth (Colman et al., 2005) suggests that there are no major gaps in the record.

\subsection{Mineralogy}

The hydrologic and chemical evolution of Bear Lake is reflected in both the allogenic and endogenic minerals found in the sediments. Sediments deposited between 26 and 18 cal ka consist predominantly of quartz with minor amounts of low-Mg calcite and dolomite (Unit 1, Fig. 5). The quartz (and minor feldspar, not shown) is detrital, brought in by the Bear River during the last glacial interval (LGI; 24-15 cal ka). Some or all of the low-Mg calcite and dolomite deposited during this time also may be detrital. Most of core 96-3, like the bottom of core 96-2, consists predominantly of quartz with minor low-Mg calcite, dolomite, and feldspar. Sediments of late glacial age $(18-16 \mathrm{cal} \mathrm{ka})$ in core 96-2 are characterized by decreasing amounts of quartz, suggesting that the Bear River was in the process of abandoning Bear Lake, and they also contain increasing amounts of calcite, indicating increased precipitation of endogenic $\mathrm{CaCO}_{3}$ (Unit 2, Fig. 5). Sediments deposited during the transition between the LGI and Holocene $(16-11 \mathrm{cal} \mathrm{ka})$ consist of about $40 \%$ $\mathrm{CaCO}_{3}$ as low-Mg calcite, about $30 \%$ quartz, and minor dolomite and aragonite (Unit 3, Fig. 5). The percentage of low-Mg calcite in Unit 3 calculated from XRD peak height is about $60 \%$ (Fig. 4). The peak-height method overestimates $\%$ calcite and underestimates \% quartz and \% aragonite. The true quartz content in Unit 3 probably is more like $50-60 \%$.

Precipitation of $\mathrm{CaCO}_{3}$ abruptly changed from predominantly calcite to predominantly aragonite at about 11 cal ka (Unit 3-4 boundary, Fig. 5). Aragonite precipitation dominated deposition for about $2 \mathrm{ky}$ (Unit 4, Fig. 5), then, just as abruptly, returned to
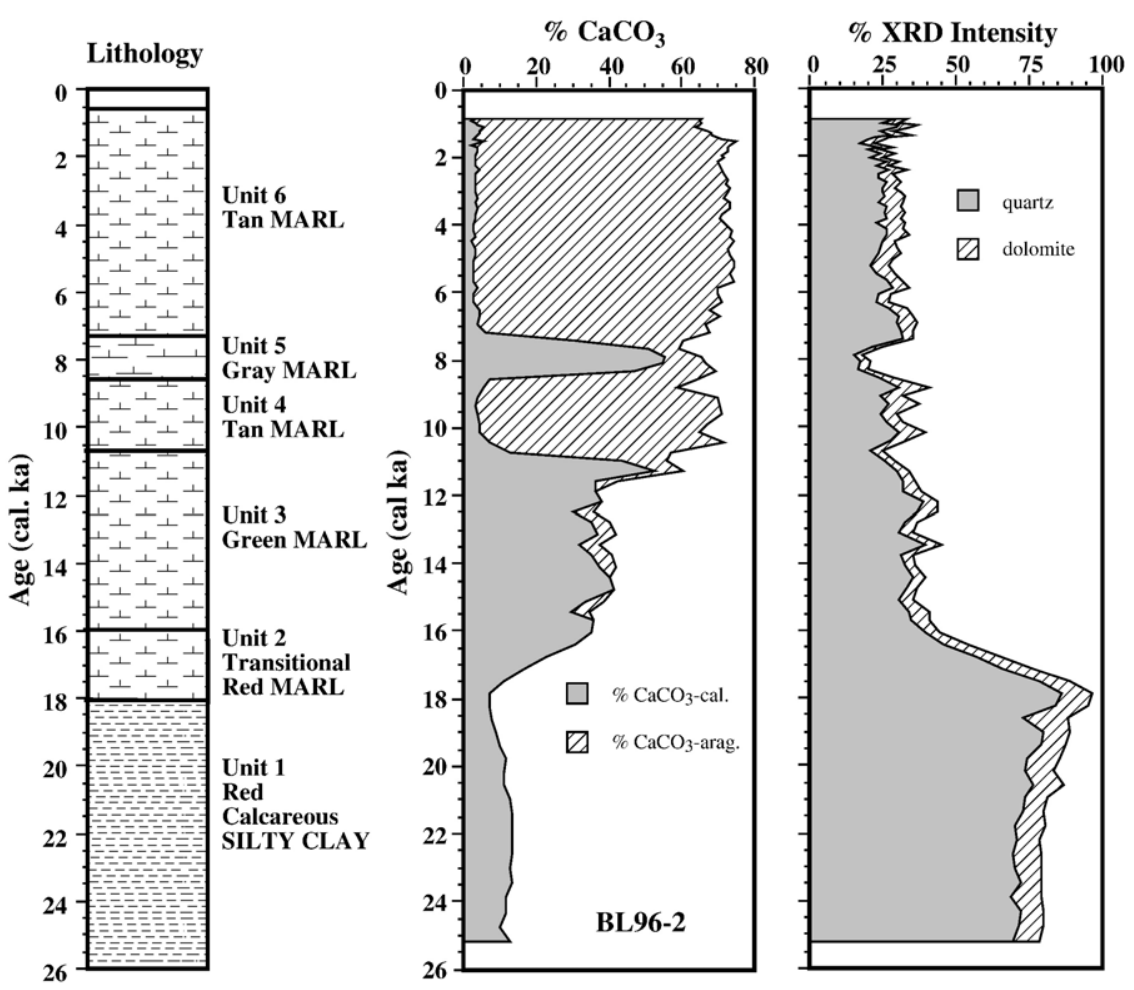

Fig. 5. Lithology and profiles of percent $\mathrm{CaCO}_{3}$ as aragonite and calcite (see text for method of calculation), and percentages of dolomite and quartz (calculated from XRD peak intensities), all versus age (in cal ka), for core 96-2. 
calcite precipitation for another $1 \mathrm{ky}$ (Unit 5, Fig. 5). By $7 \mathrm{cal} \mathrm{ka,} \mathrm{aragonite} \mathrm{again} \mathrm{dominated} \mathrm{the} \mathrm{sediments,}$ with minor quartz, low-Mg calcite, and dolomite (Unit 6, Fig. 5). This mode of carbonate sedimentation continued for the rest of the Holocene. Core 96-1, like Unit 6 in core 96-2, consists predominantly of aragonite with minor low-Mg calcite (Fig. 4), dolomite, and quartz. Note that the percent aragonite in core 96-2 calculated from XRD peak intensities (Fig. 4) is greatly underestimated, and percent calcite greatly overestimated. This is because of the large difference in the X-ray mass absorption characteristics of the two minerals. The partitioning of $\mathrm{CaCO}_{3}$ between aragonite and calcite based on peak intensity ratios (Eq. (1)) gives a more accurate estimate of the proportion of aragonite to calcite (Fig. 5).

\subsection{Magnetic properties}

Values of MS and HIRM can be used to document differences in magnetic mineralogy within the Bear Lake and Bear River catchments (Fig. 6). Based on these magnetic properties, the sampled region (Fig. 3) can be divided into three areas. First, sediments in the local catchment of Bear Lake are characterized by MS values that are about three times higher than those along the Bear River. Second, the Bear River above Bear Lake and below the Utah-Wyoming border is characterized by low values of both MS and HIRM. Third, the Bear River south of Wyoming is characterized by low MS but high HIRM, probably arising from hematite-cemented Neoproterozoic rocks in the Uinta Mountains (Ashby et al., 2001). This hematite cement may be the main source of high iron $(\mathrm{Fe})$ contents of Bear River sediments (Fig. 6), although red iron oxide coatings also supply some of the Fe. The Fe content of Bear River sediments decreases more gradually than HIRM downstream from the Uinta Mountains.

Variations in magnetic properties in core 96-2 in part reflect differences in magnetic properties of the source areas of detrital clastic material. In comparison to the entire core, the lower part of Unit 1 is characterized by high HIRM and moderate MS (Fig. 7). Values of HIRM and MS are consistent with sediment older than 24 cal ka being comprised mostly of hematite-rich sediment derived from the headwaters of Bear River in the Uinta Mountains. No other source of sediment can explain the high values of HIRM without calling upon some mechanism to concentrate the high-coercivity magnetic phases in the lake sediments. The hematite-rich material is interpreted to be glacial flour because (1) a large fraction of the sediment

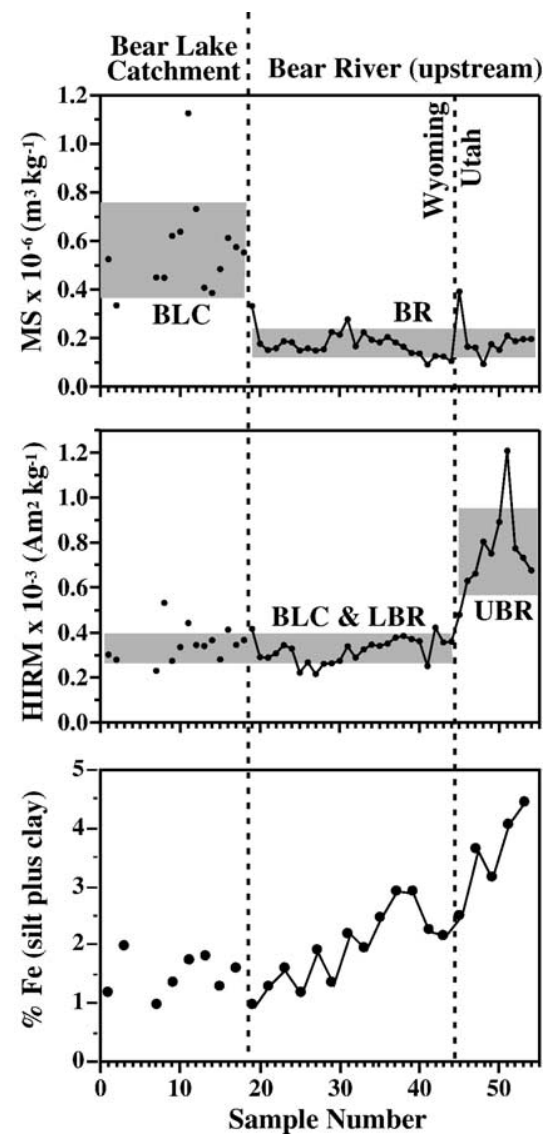

Fig. 6. Magnetic susceptibility (MS), hard isothermal remnant magnetization (HIRM), and percent Fe of the silt plus clay fractions of catchment samples. Sample locations are shown in Fig. 3. The shaded boxes are centered on mean MS and HIRM values for Bear River (BR), upper Bear River (UBR), Bear Lake catchment (BLC), and BLC plus lower Bear River (LBR). The boxes extend to one standard deviation on either side of the mean.

apparently was derived from a small fraction of the Bear River catchment that was glaciated during the LGI, and (2) the age of this part of the section falls within the LGI. Attribution of these sediments to a source in the Uinta Mountains requires that the Bear River was connected to Bear Lake at this time.

After 25 cal ka, HIRM decreased to a local minimum at about $23 \mathrm{cal} \mathrm{ka}$, increased for a brief interval, and then began a long decrease to about $11 \mathrm{cal} \mathrm{ka}$. In the lower part of this interval (upper part of Unit 1; Fig. 7) MS varies inversely with HIRM until reaching a maximum at about $18 \mathrm{cal} \mathrm{ka}$. The inverse relation between HIRM and MS suggests that the content of hematite-rich glacial flour from the Uinta Mountains decreased and was replaced by sediment derived from other parts of the catchment including material with relatively high MS values from the local Bear Lake catchment. Values of HIRM at $18 \mathrm{cal} \mathrm{ka}$ are consistent 

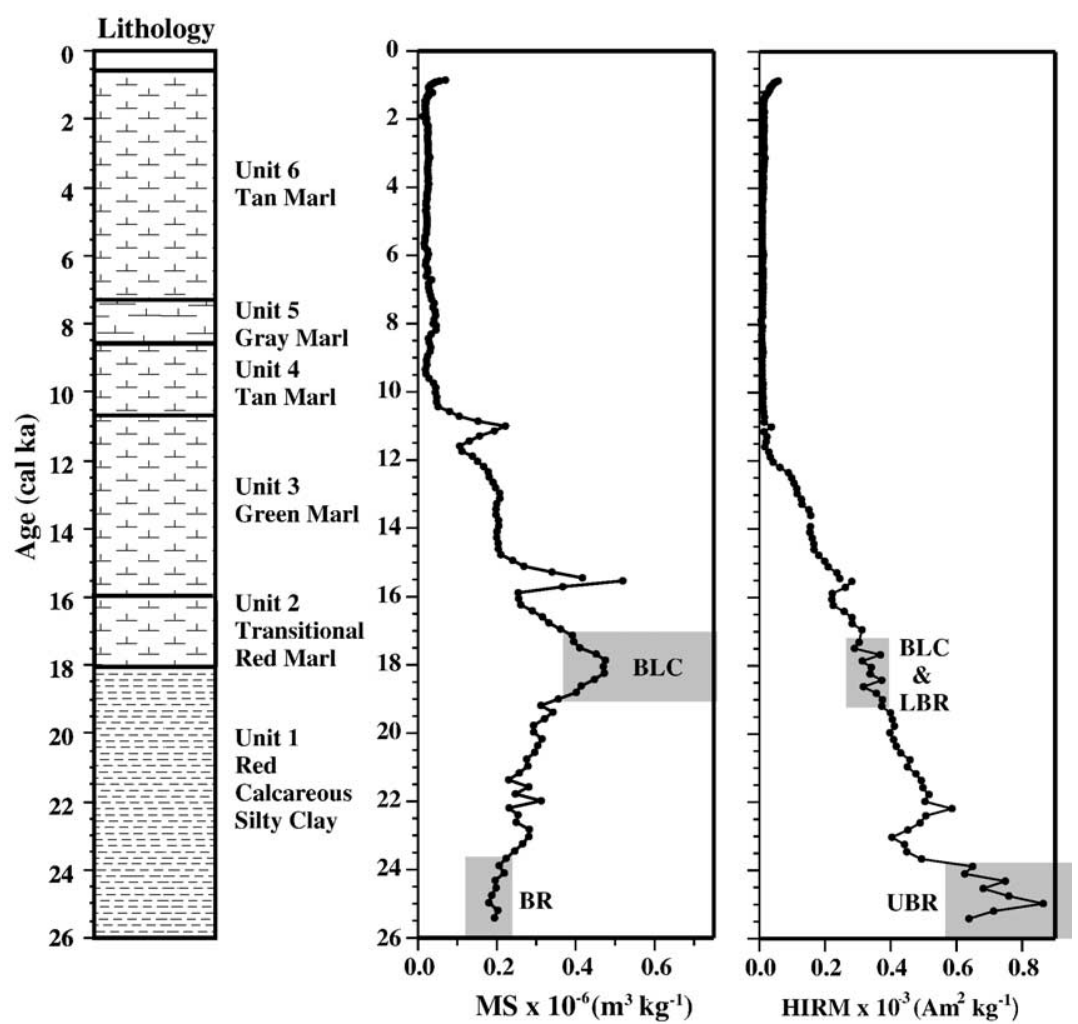

Fig. 7. Lithology, magnetic susceptibility (MS), and hard isothermal remnant magnetization (HIRM) versus age in core 96-2. The shaded boxes extend to one standard deviation on either side of the mean for catchment samples from the areas indicated in Fig. 6.

with sediment composed of detrital material containing little, if any, material from the Uinta Mountains. The MS values in sediment at the top of Unit 1 indicate that it contains about $75 \%$ material from the local Bear Lake catchment and $25 \%$ from Bear River.

Above Unit 1, both MS and HIRM decrease upwards. Two well-defined peaks in MS interrupt this trend to lower values. The origins of these peaks are not firmly established, but magnetite was observed in a few glass shards in a magnetite separate from the upper of these two peaks (R. Reynolds, written communication, 2004), suggesting that this peak is due to disseminated volcanic ash. The two peaks have similar wavelengths and shapes suggesting similar origins. The decreases in HIRM and MS across Unit 2 (by factors of 1.5 and 2, respectively) can be largely explained by dilution of detrital material by endogenic carbonate (Fig. 5). The further upward decrease in HIRM and MS throughout Unit 3 and into the base of Unit 4 cannot be explained by further dilution because the change in content of detrital material (e.g., quartz; Fig. 5) is relatively small, whereas both HIRM and MS decline by more than an order of magnitude. In Holocene sediments, ferrimagnetic minerals have been so thoroughly destroyed by post-depositional alteration that paramagnetic minerals probably account for a significant fraction of MS.

\subsection{Carbon content}

Although the carbonate minerals in Holocene sediments in core 96-2 are a mixture of calcite and aragonite (with minor dolomite), the overall bulk $\mathrm{CaCO}_{3}$ content is relatively constant at about $70 \%$ (Fig. 8). This suggests that there was a mass balance of total $\mathrm{CaCO}_{3}$ that was maintained through changes in mineralogy, which presumably reflect changes in environmental conditions (discussed below). The increase in $\mathrm{CaCO}_{3}$ in Holocene sediments, relative to LGI sediments, could represent an increase in the rate of $\mathrm{CaCO}_{3}$ accumulation in the sediments, or it could represent lack of dilution by detrital clastic material (the red clay) that dominated the LGI sediments. We used sedimentation rates, calculated from the age model, and measured dry bulk densities to calculate bulk-sediment mass accumulation rates (MAR), and MARs of $\mathrm{CaCO}_{3}$ and $\mathrm{OC}$ (Fig. 8). The MAR of $\mathrm{CaCO}_{3}$ does show considerable variation throughout the Holocene section, 

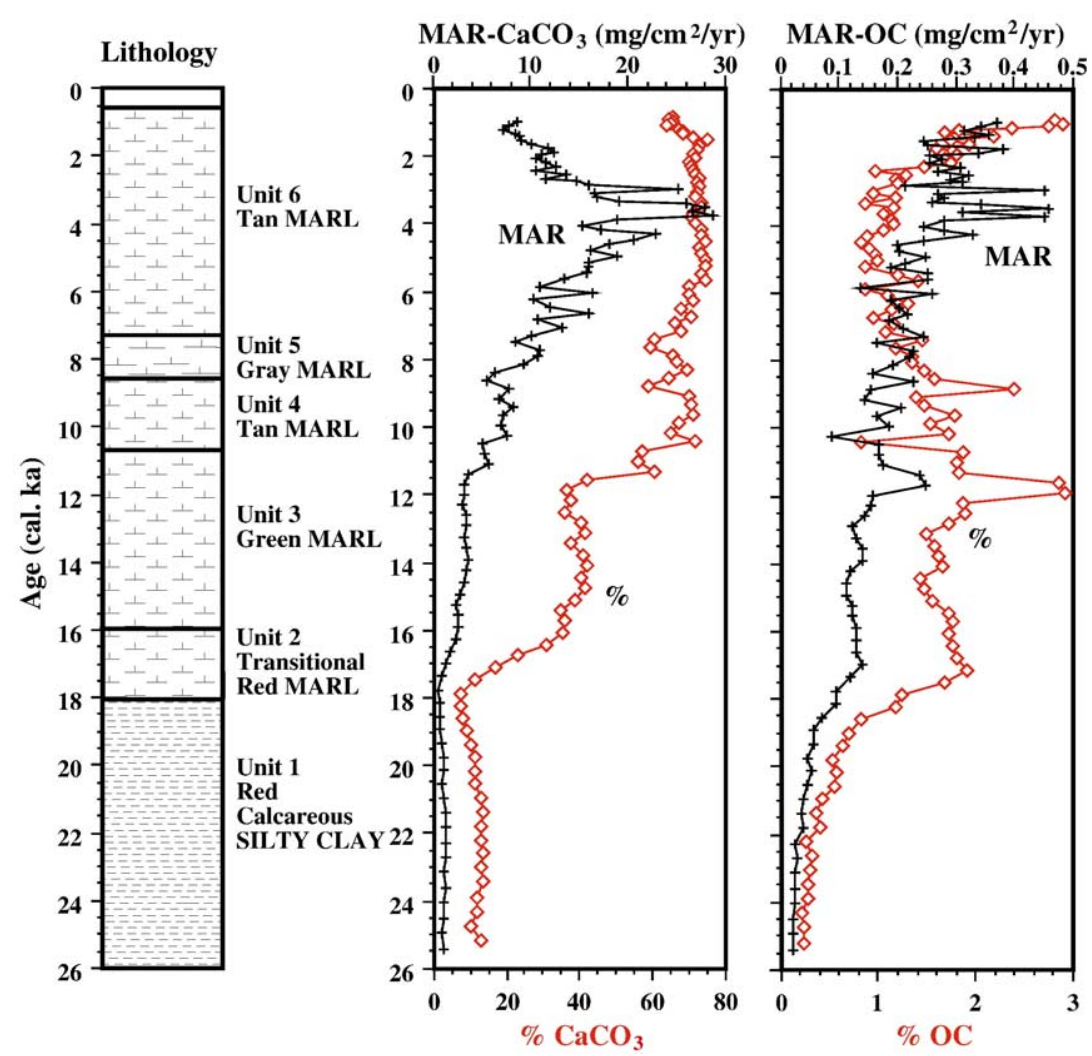

Fig. 8. Lithology, and profiles of percentages and mass accumulation rates (MAR) of $\mathrm{CaCO}_{3}$, and organic carbon (OC) versus age in core 96-2.

peaking in sediments deposited between 3 and 4 cal ka. In the late glacial-age sediments that contain only calcite (16 to $11 \mathrm{cal} \mathrm{ka}$ ), the overall $\mathrm{CaCO}_{3}$ content is about $40 \%$ (Fig. 5). Smoot (2005) described the finegrained sediments deposited during the glacial-Holocene transition and all of the Holocene as various colored "clays". The $\mathrm{CaCO}_{3}$ content of all of these sediments is high enough $(>30 \%)$ to classify them as marls (Dean, 1981; Fig. 8). The red clayey glacial sediments contain enough $\mathrm{CaCO}_{3}$ (about $5 \%$ ) to be classified as calcareous clay. These red, carbonatepoor LGI sediments are in marked contrast to the light tan, aragonitic Holocene marls (Fig. 5).

The OC content of glacial-age sediments is $<0.5 \%$, but increases gradually to about $2.0 \%$ in sediments deposited about 17 cal ka (Fig. 8). The OC content decreases in Holocene sediments (from about $2.0 \%$ to $1.0 \%$ ), but increases abruptly in sediments deposited between 3 and 1 cal ka to almost 3\%. The OC MAR, like \% OC, increases upward in glacial sediments, fluctuates considerably in Holocene sediments, and, like $\mathrm{CaCO}_{3}$ MAR, peaks in sediments deposited between 3 and 4 cal ka (Fig. 8). The gradual increases in percentage and MAR of OC throughout the LGI suggest that lake productivity was increasing through the LGI.

\subsection{Carbon and oxygen isotopes}

The range of values of $\delta^{18} \mathrm{O}(8 \%)$ and $\delta^{13} \mathrm{C}(6 \%)$ in carbonate is considerable (Fig. 9). Values of $\delta^{18} \mathrm{O}$ and $\delta^{13} \mathrm{C}$ in Holocene marls of a typical hard-water, through flowing, hyrdologically open, north-temperate lake usually vary by $2-4 \%$ (e.g., Talbot, 1990). In general, values of both $\delta{ }^{18} \mathrm{O}$ and $\delta^{13} \mathrm{C}$ increase from glacial to Holocene sediments, but with considerable, and important, fluctuations, particularly in values of $\delta^{18} \mathrm{O}$ (Fig. 9). A high positive covariance exists between $\delta^{18} \mathrm{O}$ and $\delta^{13} \mathrm{C}$ in marls deposited after 16 cal ka (Fig. 10A). This correlation is independent of carbonate mineralogy (aragonite or calcite), but, as can be seen in Fig. 9, values of $\delta^{18} \mathrm{O}$ tend to be lower (more negative) in intervals dominated by calcite than in those dominated by aragonite. Values of $\delta^{13} \mathrm{C}$ also are lower in the calcite deposited between 9 and $7 \mathrm{cal} \mathrm{ka} \mathrm{(Fig.} \mathrm{9).} \mathrm{Values} \mathrm{of} \delta^{13} \mathrm{C}$ in calcite that is present in low amounts in glacial sediments deposited before $18 \mathrm{ka}$ are depleted in ${ }^{13} \mathrm{C}$ by about $2 \%$ relative to the more abundant calcite deposited between 16 and 12 cal ka (Figs. 9 and 10A). The glacial-age sediments are even more depleted than the carbonate rocks (limestones and dolomites) in the Bear River Range to the west of the lake as indicated by an average value of $\delta^{13} \mathrm{C}$ of $0.13 \%$ 。 


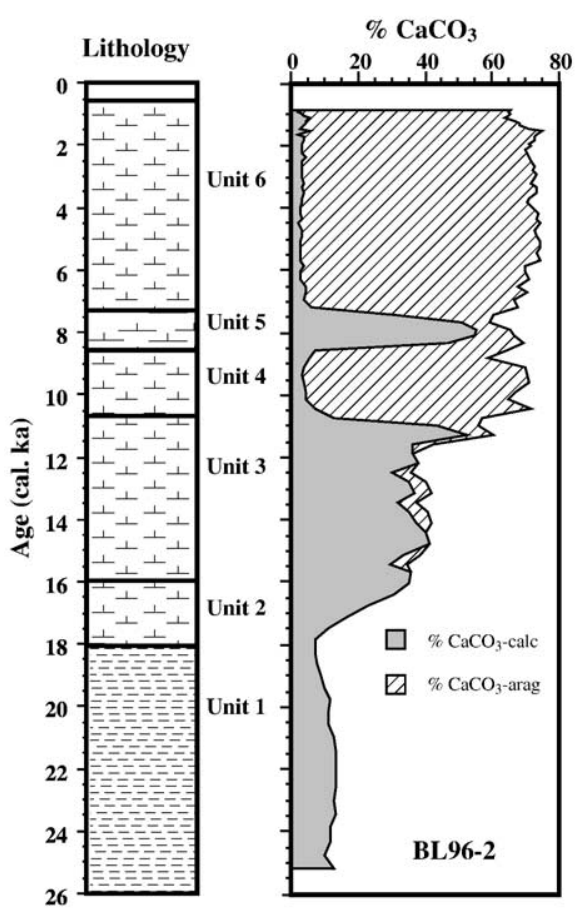

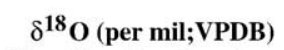

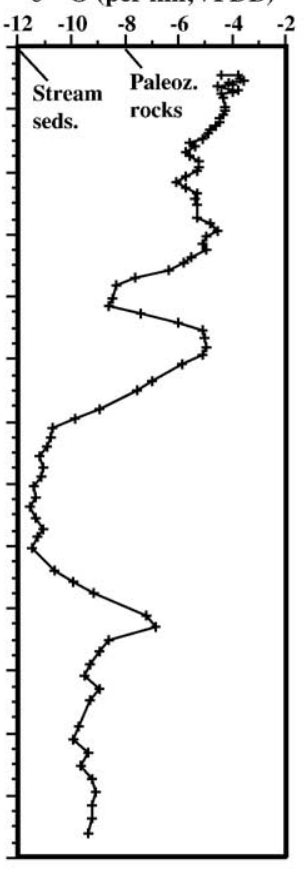

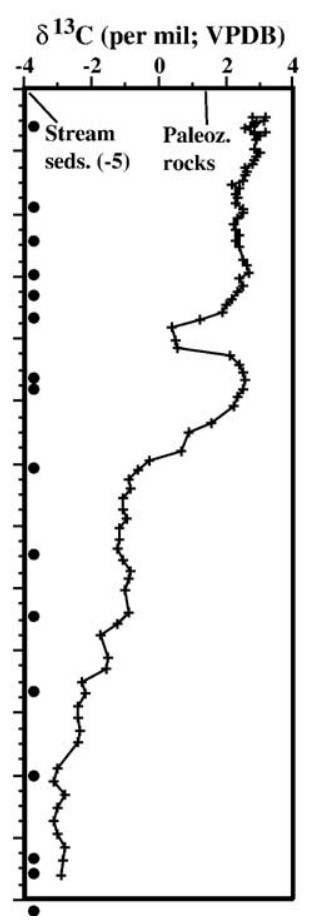

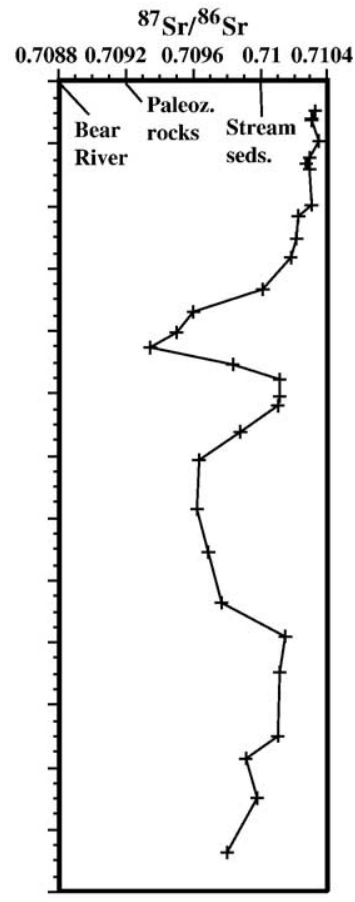

Fig. 9. Lithology, and profiles of percent $\mathrm{CaCO}_{3}$ as aragonite and calcite (see text for method of calculation), and of $\delta^{18} \mathrm{O}, \delta^{13} \mathrm{C}$, and ${ }^{87} \mathrm{Sr} /{ }^{86} \mathrm{Sr}$ in bulk carbonate versus age in core 96-2. The black dots on the left margin of the profile for $\delta^{13} \mathrm{C}$ are the locations of radiocarbon dates.

(range, -2 to $2.8 \%$ ) in 10 samples of these rocks (Bright et al., in press). Values of $\delta^{18} \mathrm{O}$ in glacial-age sediments are similar to those in the same 10 samples of Paleozoic carbonate rocks (average, $-7.9 \%$ o: range, -13 to $-5 \%$ ).

A positive covariance between values of $\delta^{18} \mathrm{O}$ and $\delta^{13} \mathrm{C}$ in lacustrine carbonates often occurs in water bodies with relatively long residence times, and if the correlation is high $(r>0.7)$, this implies that the lake was hydrologically closed (Talbot, 1990). Covariant trends may have remarkably long-term persistence through major environmental changes (Talbot, 1990), and this certainly applies to Bear Lake.

Values of $\delta^{18} \mathrm{O}$ and $\delta^{13} \mathrm{C}$ in the aragonite in upper Holocene marls recovered in cores 96-1 (Fig. 10B) and 96-2 (Fig. 10A) are highly enriched in ${ }^{18} \mathrm{O}$ and ${ }^{13} \mathrm{C}$ relative to the calcite-rich marls deposited during the glacial-Holocene transition (Figs. 9 and 10A). Similarly, low-Mg calcite in glacial-age calcareous clay in core 963 has values of $\delta^{18} \mathrm{O}$ and $\delta^{13} \mathrm{C}$ (Fig. 10B), which are comparable to those in glacial-age calcareous clay in core 96-2 (Fig. 10A).

\subsection{Strontium isotopes}

Overall the profile of ${ }^{87} \mathrm{Sr} /{ }^{86} \mathrm{Sr}$ ratios in carbonate samples from core 96-2 is similar to those of $\delta^{13} \mathrm{C}$, and ${ }^{18} \mathrm{O}$, although there are fewer analyses (Fig. 9). The very low ${ }^{87} \mathrm{Sr} /{ }^{86} \mathrm{Sr}$ ratios in Bear River water $(0.7088$; Fig. 9) should be an excellent tracer (Bouchard et al., 1998) of when Bear River entered Bear Lake. Based on this criterion, it appears that some Bear River water was entering the lake prior to $12 \mathrm{cal} \mathrm{ka}$, and between 9 and 7 cal ka, an interpretation that is consistent with carbon and oxygen isotope data also indicating reentry of Bear River. Ratios of ${ }^{87} \mathrm{Sr} /{ }^{86} \mathrm{Sr}$ of about $\sim 0.71$ in carbonate deposited before $18 \mathrm{cal}$ ka probably represent a mixture of endogenic carbonate with values $<0.7095$ and detrital carbonate with values $>0.71$. Carbonate in the silt and clay fraction in Bear River sediments north of the Uinta Mountains have ${ }^{87} \mathrm{Sr} /{ }^{86} \mathrm{Sr}$ ratios about 0.7107 (Table 2), and the silt and clay fraction of one sample from the Uinta Mountains had a ${ }^{87} \mathrm{Sr} /{ }^{86} \mathrm{Sr}$ ratio of 0.7191 (Table 2). Ratios of ${ }^{87} \mathrm{Sr} /{ }^{86} \mathrm{Sr}>0.71$ in sediments deposited after $7 \mathrm{cal}$ ka reflects the influence of waters and carbonate sediments in west-side creeks and springs. West-side waters must have dominated the prediversion hydrologic budget of the lake by a percentage estimated to have been 95-99\% (Dean et al., 2005).

The sediments in west-side creeks contain abundant low-Mg calcite and dolomite (Table 2), presumed to be derived from Paleozoic carbonate rocks in the Bear River Range to the west of the lake. However, the average ${ }^{87} \mathrm{Sr} /{ }^{86} \mathrm{Sr}$ ratio in 20 samples of these carbonate rocks is 0.7092 (range 0.7071-0.7161; Bright et al., in 

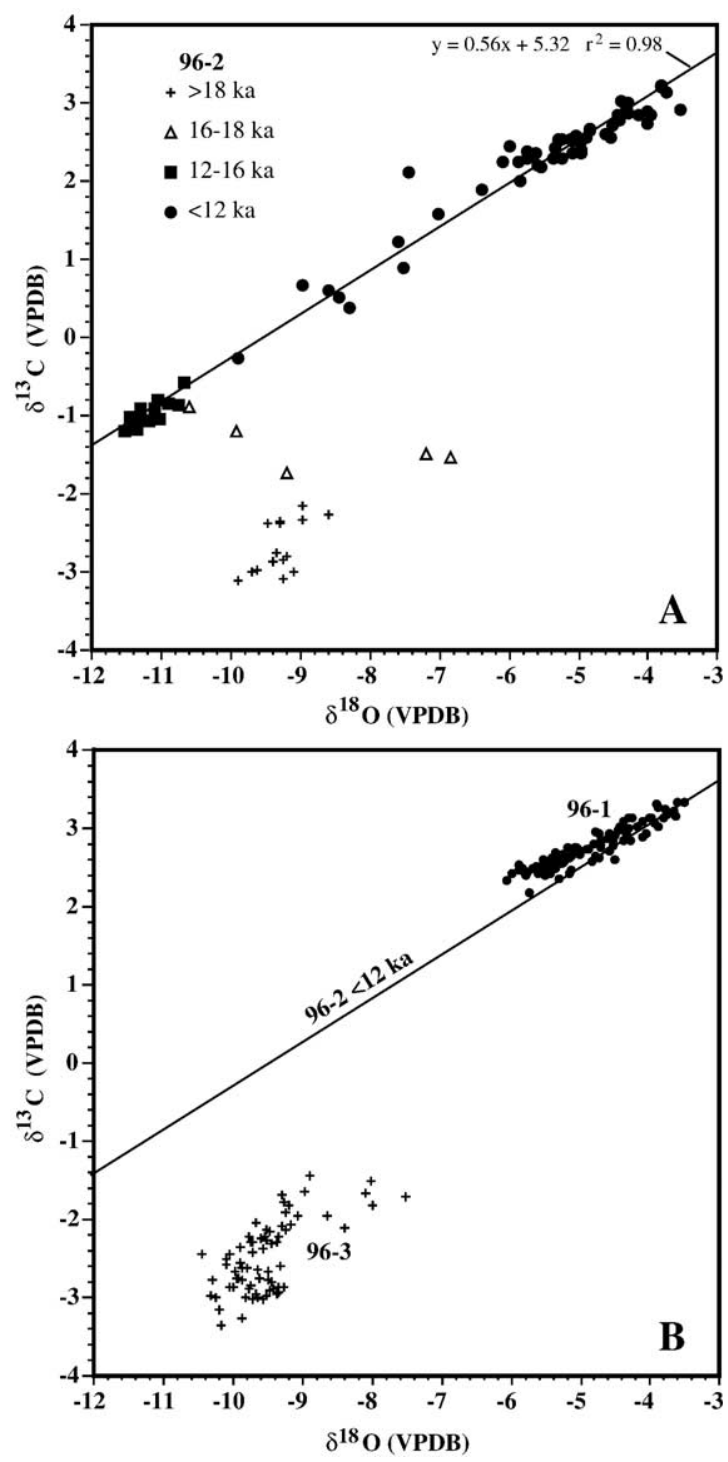

Fig. 10. Cross plots of values of $\delta^{18} \mathrm{O}$ and $\delta^{13} \mathrm{C}$ in samples from core 96-2 (A), and cores 96-1 and 96-3 (B). The regression line and equation in panel $\mathrm{A}$ is for samples from 96-2 younger than $12 \mathrm{ka}$; the regression line is repeated in panel $\mathrm{B}$.

press), which is depleted relative to bulk carbonate in stream sediments (Table 2). Endogenic tufa picked from the sediments of several west-side streams have ${ }^{87} \mathrm{Sr} /{ }^{86} \mathrm{Sr}$ ratios that are similar to those in bulk carbonate in stream sediments $(0.710+$; Table 2$)$, and similar to ratios in bulk carbonate deposited in the lake over the last 4000 years (Fig. 9).

\subsection{Leach chemistry}

Concentrations of $\mathrm{HCl}$-extractable elements in bulk carbonate generally reflect the mineralogy of the sedi- ments. Highest concentrations of $\mathrm{Mg}$ and $\mathrm{Mg} / \mathrm{Ca}$ ratios generally are associated with low-Mg calcite and the red clay, which contains dolomite, whereas highest concentrations of $\mathrm{Sr}$ and $\mathrm{Ba}$, and highest $\mathrm{Sr} / \mathrm{Ca}$ ratios, are associated with aragonite (Fig. 11). Slightly elevated $\mathrm{Ba}$ concentrations in the calcareous red clay probably are due to substitution of $\mathrm{Ba}$ for $\mathrm{Ca}$ in detrital carbonate. The average bulk-sediment $\mathrm{Ba}$ concentration in the silt and clay fraction of carbonate-bearing stream sediments in the Bear River south of Bear Lake is $400 \mathrm{ppm}(n=14$; samples 17-53, Fig. 3) with maximum values of 1000 (samples 51 and 53). The peak in $\mathrm{Mg} / \mathrm{Ca}$ in sediments deposited about 18 cal ka (Fig. 11) may be due to an influx of dolomite from the west-side creeks because the high MS values in those sediments (Fig. 7) suggest a predominance of sediment from the local Bear Lake catchment. However, the ${ }^{87} \mathrm{Sr} /{ }^{86} \mathrm{Sr}$ ratios in sediments deposited in the lake over the last 4000 years are more indicative of those in endogenic carbonate than in Paleozoic carbonate rocks (Fig. 9). Paleozoic carbonate rocks have much lower ${ }^{87} \mathrm{Sr} /{ }^{86} \mathrm{Sr}$ ratios (ca. 0.7092), but there is no indication of sediments with these lower ratios entering the lake.

The calcareous red clay deposited during the LGI when Bear River was connected to Bear Lake contains relatively high concentrations of $\mathrm{Mn}$ and Fe (Fig. 11), some of which was extracted by the HCL leach. Concentrations of $\mathrm{Fe}$ are expressed on a carbonate-free (cf) basis to remove the dilution effect of $\mathrm{CaCO}_{3}$, thereby revealing actual changes in the character of $\mathrm{Fe}$ in the noncarbonate fraction. Concentrations of $\mathrm{Fe}$ in the silt plus clay fractions of bulk stream-sediment samples from the Uinta Mountains are up to $4.5 \%$ (Fig. 6). Much if not most of the $\mathrm{Fe}$ probably is present as hematite based on the high HIRM values (Fig. 6), but some is present as iron oxide coatings on the red silty clay. Some of the Mn probably is present as oxyhydroxides particularly in the red silty clay, but the relatively high Mn contents of the calcite formed at about $8 \mathrm{cal}$ ka and prior to $11 \mathrm{cal} \mathrm{ka} \mathrm{(Fig.} \mathrm{11)} \mathrm{indicate} \mathrm{that} \mathrm{Mn} \mathrm{also}$ is substituting for $\mathrm{Ca}$ in calcite.

\section{Discussion: the glacial-Holocene evolution of the Bear Lake chemical system}

\subsection{Evolution of other Lakes in the Great Basin}

The presence of red calcareous clay deposited in Bear Lake during the LGI coincides in time with the growth of large lakes in the northern Great Basin, including Bonneville, Lahontan, and Russell (Thompson, 1990; Thompson et al., 1986, 1993; Benson and 
Table 2

X-ray diffraction (XRD) mineralogy and oxygen, carbon, and strontium isotopic composition of the silt + clay $(<63$ um) fraction of stream sediments in the Bear Lake catchment

\begin{tabular}{|c|c|c|c|c|c|c|c|c|}
\hline Bear River spl. \# stream & $\%$ quartz & $\%$ dolomite & $\%$ calcite & $\%$ feldspar & $\% \mathrm{CaCO}_{3}$ & del ${ }^{18} \mathrm{O}$-carb & del ${ }^{13} \mathrm{C}$-carb & $87 \mathrm{Sr} / 86 \mathrm{Sr}$ \\
\hline \multicolumn{9}{|l|}{ West-Side Creeks } \\
\hline 1 Paris Creek & 41.61 & 55.62 & 0.00 & 2.76 & 0.0 & -14.3 & -6.06 & \\
\hline 1 Paris Creek & & & & & & -8.4 & -0.20 & \\
\hline 3 Hobble Creek & 68.57 & 2.88 & 13.64 & 14.91 & 15.7 & -12.4 & 1.20 & \\
\hline 7 St. Charles Creek & 51.99 & 36.05 & 5.58 & 6.38 & & -13.0 & -5.74 & 0.71004 \\
\hline 9 Fish Haven Creek & 57.84 & 25.60 & 11.48 & 5.07 & & & & 0.71030 \\
\hline 11 Hodges Canyon & 81.42 & 2.88 & 4.81 & 10.90 & 0.0 & -14.9 & -8.20 & \\
\hline Swan Creek & & & & & & -13.4 & -5.20 & \\
\hline Bloomington Creek & & & & & & -15.8 & -7.20 & \\
\hline \multicolumn{9}{|l|}{ East-Side Creeks } \\
\hline 13 South Eden Cyn. & 63.44 & 4.35 & 28.09 & 4.12 & 25.6 & -13.4 & -7.25 & \\
\hline 13 South Eden Cyn. & & & & & & -11.4 & -5.00 & \\
\hline 15 North Eden Cyn. & 84.60 & 3.28 & 8.20 & 3.93 & 10.8 & -13.5 & -4.76 & \\
\hline 15 North Eden Cyn. & & & & & & -12.4 & -5.00 & \\
\hline 17 Indian Creek & 69.24 & 2.74 & 21.15 & 6.86 & & -11.6 & -4.49 & 0.70768 \\
\hline \multicolumn{9}{|l|}{ B.R. N. of Uintas } \\
\hline Bear River & & & & & & -12.6 & -4.80 & \\
\hline Bear River & & & & & & -12.8 & -6.54 & \\
\hline 19 Bear River & 84.67 & 2.94 & 8.95 & 3.44 & 9.9 & -12.7 & -5.00 & \\
\hline 21 Bear River & 75.25 & 8.45 & 11.26 & 5.04 & & & & 0.70907 \\
\hline 23 Bear River & 78.14 & 4.49 & 11.37 & 5.99 & 12.1 & -11.5 & -4.00 & \\
\hline 25 Bear River & 81.31 & 4.98 & 6.54 & 7.17 & 11.3 & -11.9 & -5.40 & \\
\hline 27 Bear River & 74.97 & 5.57 & 16.03 & 3.43 & & & & 0.71067 \\
\hline 29 Bear River & 84.98 & 3.07 & 9.56 & 2.39 & 13.2 & -12.8 & -5.70 & \\
\hline 31 Bear River & 76.94 & 5.53 & 16.60 & 4.15 & & & & 0.71078 \\
\hline 33 Bear River & 85.29 & 5.19 & 8.76 & 2.98 & 4.5 & -12.2 & -5.00 & \\
\hline 35 Bear River & 80.46 & 6.11 & 12.34 & 8.11 & 11.6 & -11.4 & -5.90 & \\
\hline 37 Bear River & 82.73 & 5.96 & 9.95 & 9.08 & & & & \\
\hline 39 Bear River & 84.72 & 5.79 & 8.48 & 4.39 & 8.0 & -10.0 & -5.00 & \\
\hline 41 Bear River & 76.95 & 7.39 & 14.52 & 5.92 & 12.9 & -10.1 & -5.30 & \\
\hline 43 Bear River & 70.16 & 8.89 & 19.74 & 10.20 & 22.2 & -9.3 & -3.50 & \\
\hline \multicolumn{9}{|l|}{ B.R. in Uintas } \\
\hline 45 Bear River & 71.62 & 5.34 & 21.60 & 11.58 & & & & \\
\hline 51 Bear River & 83.14 & 0.00 & 0.00 & 16.86 & & & & \\
\hline 53 Bear River & 87.76 & 0.00 & 0.00 & 12.24 & & & & 0.71910 \\
\hline
\end{tabular}

See Fig. 3 for sample locations.

XRD percentages were calculated from peak intensities.

Isotope data are on the carbonate fraction.

Thompson, 1987; Currey, 1990). At that time, Bristlecone Pine occupied the present Piñon/Juniper life zone implying that the climate was somewhat wetter, and summer temperatures were as much as $10^{\circ}$ below modern. The increased moisture was due to increased winter precipitation produced by enhanced cyclonic flow (i.e., increased domination of the Aleutian lows) (Kutzbach et al., 1993). This change in circulation apparently was caused by a splitting of the polar jet stream, and southerly displacement of the southern branch of the jet (Kutzbach, 1987; COHMAP Members, 1988). Precipitation is greatest under the axis of the polar jet, decreases abruptly south of the axis, and decreases less abruptly north of the axis. Consequently, the Great Basin was wetter during the LGI and the Pacific Northwest was drier (Barnowsky et al., 1987; Thompson et al., 1993). This precipitation effect would have been enhanced by the temperature contrast between the Laurentide ice sheet to the north and the relatively warm sea-surface temperatures along the Pacific coast that likely intensified the jet. Sediments deposited during the LGI in Owens Lake in southeastern California at a latitude of $36.5^{\circ} \mathrm{N}$ contain an ostracode assemblage dominated by Cytherissa lacustrus, which indicates very cold, stable 

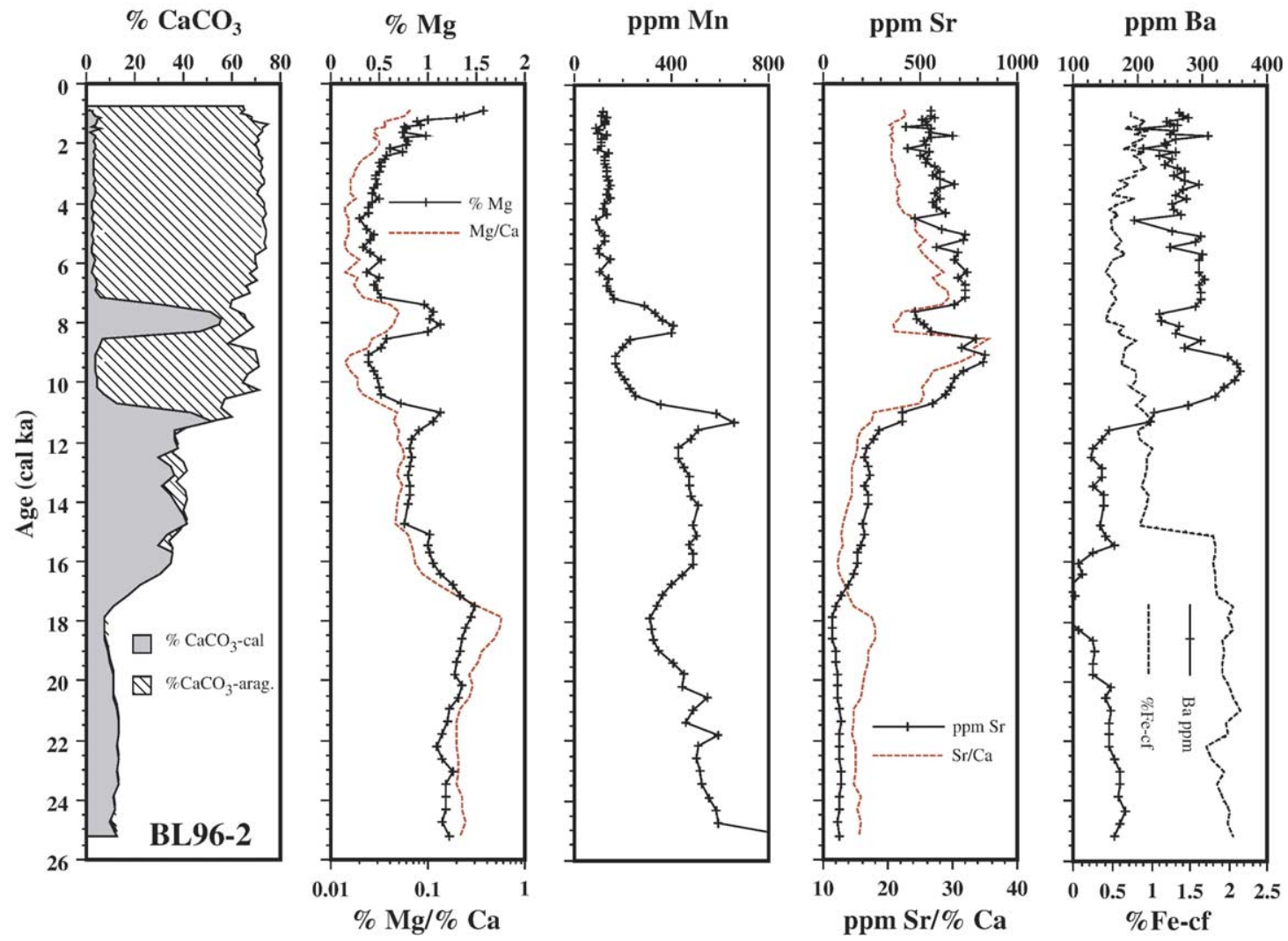

Fig. 11. Profiles of percent $\mathrm{CaCO}_{3}$ as aragonite and calcite, and $\mathrm{HCl}$-soluble $\% \mathrm{Mg}, \mathrm{Mg} / \mathrm{Ca}$ ratio, ppm $\mathrm{Mn}, \mathrm{ppm} \mathrm{Sr}, \mathrm{Sr} / \mathrm{Ca}$ ratio, ppm Ba, and \% Fe on a carbonate-free (cf) basis in bulk carbonate versus age in core 96-2.

limnoclimatic conditions (Bradbury and Forester, 2002). Based on the modern distribution of $C$. lacustrus, its presence in large numbers implies that polar air masses were present year-round at the latitude of Owens Lake. It is difficult to determine how much wetter the LGI was, but modeling studies (Hostetler et al., 1994) indicate that the presence of the lakes had a considerable influence on the precipitation over these large lake basins. This study estimates that at $20 \mathrm{cal} \mathrm{ka,} \mathrm{precipitation} \mathrm{in} \mathrm{the} \mathrm{Bonne-}$ ville basin with the lake was 3\% greater in January and $38 \%$ greater in July than it was without the lake due to lake-atmosphere feedbacks.

Lakes in the southern Great Basin reached their maximum levels during the LGI. Pluvial Lakes Manix and Mojave were overflowing into pluvial Lake Manly (Death Valley) as early as $24 \mathrm{cal}$ ka until about $17 \mathrm{cal} \mathrm{ka}$ (Enzel et al., 2003; Wells et al., 2003). During the LGI, Lake Estancia in central New Mexico reached its highest and most persistent stand (Allen and Anderson, 1993, 2000: Anderson et al., 2002), and a lake occupied the San Agustin Plains of west-central New Mexico (Markgraf et al., 1984). Also during the LGI, major wetlands occupied the now dry basins in southern
Nevada (Quade et al., 2003 and references therein). Because precipitation decreases rapidly south of the polar jet, the presence of persistent lakes and wetlands in the southern Great Basin suggests that the storm tracks that delivered this moisture must have been at latitudes between $32^{\circ}$ and $35^{\circ} \mathrm{N}$ (e.g., Enzel et al., 2003).

Although the levels of the large lakes in the northern Great Basin continued to increase during the LGI, they did not reach their maximum levels until after 18 cal ka, followed by precipitous decreases (Benson and Thompson, 1987; Thompson et al., 1986, 1993; Currey, 1990; Oviatt et al., 1992). This suggests that the moisturedelivering storm tracks migrated northward at about 17 cal ka, when the pluvial lakes of the southern Great Basin began to dry up, and Lakes Bonneville and Lahontan in the northern Great Basin approached maximum levels.

\subsection{Evolution of Bear Lake}

Even at it's highest elevation (1620 masl), Lake Bonneville was still more than $100 \mathrm{~m}$ below the level 
of Bear Lake (ca. 1805 masl today). However, the increased precipitation that caused the expansion of Bonneville, together with the lake-effect increase in precipitation due to Bonneville itself (Hostetler et al., 1994), undoubtedly increased the flow of the Bear River so that the river and lake were connected. The most likely place for the two to be connected is at the north end where the present threshold of Bear Lake is only about $2 \mathrm{~m}$ above modern lake level (Laabs and Kaufman, 2003). This connection lasted until about 18 cal ka when the quartz content began to decrease from $80 \%$ to $30 \%$ over about a 2000 -year period, and the $\mathrm{CaCO}_{3}$ content, as calcite, increased from about $10 \%$ to 40\% (Unit 2, Figs. 5 and 8).

The sediments in Bear Lake deposited prior to about 18 cal ka were dominated by detrital siliciclastics with minor amounts of low-Mg calcite and dolomite. Some of the low-Mg calcite might be endogenic but we have no way of knowing for sure. These sediments are hematite-rich (high values of HIRM; Fig. 7) indicating that they were derived mainly from glacial flour in the headwaters of Bear River in the Uinta Mountains (Fig. 6; Rosenbaum, 2005). We suggested that ${ }^{87} \mathrm{Sr} /{ }^{86} \mathrm{Sr}$ ratios in sediments deposited before $18 \mathrm{cal} \mathrm{ka}$, which are intermediate between those of stream sediments and west-side creeks $(>0.71$; Table 2$)$ and that of Bear River (0.7088; Fig. 9), might be due to a mixture of detrital and endogenic carbonate. Such a mixture also is indicated by the values of $\delta^{18} \mathrm{O}$ and $\delta^{13} \mathrm{C}$ in sediments deposited before $18 \mathrm{cal} \mathrm{ka}$. Values of $\delta^{18} \mathrm{O}$ and $\delta^{13} \mathrm{C}$ in low-Mg calcite in the red, quartz-rich LGI sediments $(-9 \%$ and $-3 \%$ ) are much lower than those of Holocene aragonite $(-4 \%$ ond $+3 \%$; Figs. 9 and 10$)$. Values of $\delta^{18} \mathrm{O}$ and $\delta^{13} \mathrm{C}$ in the silt plus clay fraction of west-side stream sediments average -14.2 and -6.1 ; those in the fine fraction of east-side stream sediments average -13.8 and -5.8 ; and those in the fine fraction of Bear River sediments average -12.7 and -5.7 (Table 2). Some of these stream sediments contain substantial amounts of low-Mg calcite and (or) dolomite (Table 2). In particular, the west-side stream sediments contain up to $55 \%$ dolomite (Table 2) due to the abundance of Paleozoic carbonate rocks, mostly dolomites, in the Bear River Range to the west of the lake. All of the values of $\delta^{18} \mathrm{O}$ and $\delta^{13} \mathrm{C}$ in detrital carbonate in stream sediments (Table 2) are much lower than those of Unit 1 sediments (Fig. 9), suggesting that the carbonate in Unit 1 sediments is a mixture of detrital and ${ }^{18} \mathrm{O}$ - and ${ }^{13} \mathrm{C}$-enriched endogenic carbonate.

Values of $\delta^{13} \mathrm{C}$ increased steadily after $22 \mathrm{cal} \mathrm{ka}$ and into the Holocene (Fig. 9), likely due to increased lake productivity and burial of ${ }^{13} \mathrm{C}$-depleted $\mathrm{OC}$ (e.g.,
McKenzie, 1985), as indicated by parallel increases in OC concentration and MAR (Fig. 8). A combination of increasing water temperature, increased evaporation, and higher organic productivity likely produced an increase in the precipitation of $\mathrm{CaCO}_{3}$ as calcite between 18 and 16 cal ka (Unit 2, Figs. 5 and 8).

As the concentration of $\mathrm{CaCO}_{3}$ in the sediments increased to $40 \%$ between 18 and $16 \mathrm{cal} \mathrm{ka}$, values of $\delta^{18} \mathrm{O}$ in bulk carbonate declined to $-11 \%$, the lowest values in the entire glacial-Holocene sequence (Fig. 9). These lower values might be due to greater influx of Bear River water, but the influx of detrital clastic material was decreasing at that time (decrease in quartz; Fig. 5), and there are no corresponding decreases in values of $\delta^{13} \mathrm{C}$ or ${ }^{87} \mathrm{Sr} /{ }^{86} \mathrm{Sr}$ (Fig. 9). In fact, the interval between 18 and $16 \mathrm{cal}$ ka is the only interval in the core where there is no covariation between $\delta^{18} \mathrm{O}$ and $\delta^{13} \mathrm{C}$ (Fig. 10A). Also, this is the time interval when the levels of Lakes Bonneville and Lahontan were rapidly decreasing, indicating that the Pacific moisture source had been cut off. The initial decline of Lake Bonneville to the Provo level at 17.5 cal ka was due to the catastrophic Bonneville flood down the Snake River, but the decline from the Provo level after about 16 cal ka was due to the warmer, drier climate (Oviatt, 1997). The low values of $\delta^{18} \mathrm{O}$ in calcite deposited between 16 and 12 cal ka are most likely due to continued abundance of cold-season precipitation (winter snow), particularly in the Uinta Mountains, the headwaters of Bear River. There is a positive covariation between $\delta^{18} \mathrm{O}$ and $\delta^{13} \mathrm{C}$ in this interval, but values of $\delta^{18} \mathrm{O}$ and $\delta^{13} \mathrm{C}$ each vary by only about $1 \%$ (Fig. 10A). We have little specific information on the deglacial history of the Uinta Mountains. Based on recessional moraine evidence, Munroe (2003) concluded that the glacier that occupied the drainage of the Henrys Fork of the Green River in the northern Uinta Mountains was present below $3300 \mathrm{~m}$ until about 10 cal ka. Woodrat midden pollen studies at Dutch John Mountain on the northeastern end of the Uinta Mountains by Jackson et al. (in press) suggest that late-glacial conditions were wetter than during the full glacial period. In general, alpine glaciers in the ranges of the Basin and Range were at their maximum extent at $20 \mathrm{cal}$ ka (Thompson et al., 1993), and persisted until about 14 cal ka (Thompson, 1990). Therefore, it is reasonable to assume that the Bear River received the bulk of its water from snow melt during the LGI, at least until about 12 $\mathrm{cal} \mathrm{ka}$, and that some of that water continued to enter Bear Lake even though the sediment supply, indicated by quartz (Fig. 5), was greatly reduced after $16 \mathrm{cal} \mathrm{ka.}$ 
By $12 \mathrm{cal} \mathrm{ka}$, values of both $\delta^{18} \mathrm{O}$ and $\delta^{13} \mathrm{C}$, but especially $\delta^{18} \mathrm{O}$, began to increase rapidly (Fig. 9), most likely due to increased evaporation. By about $11 \mathrm{cal} \mathrm{ka}$, a salinity threshold was reached and aragonite began to precipitate (Unit 3-4 boundary, Fig. 5). In the marine environment, aragonite formation relative to calcite is favored by warmer temperatures and higher salinity (e.g., Burton and Walter, 1987; Morse and Mackenzie, 1990), which is why aragonite is only found in warm, shallow marine environments. Aragonite formation in a large, cold, oligotrophic, high latitude, montane lake is highly unusual. Lacustrine aragonite usually is found in small saline lakes in which the salinity varies considerably over time. However, Bear Lake contains endemic ostracodes and four or five endemic species of fish (Wurtsbaugh and Luecke, 1997), which indicate that the chemistry of the lake has remained fairly constant for a long time. The production of large quantities of aragonite under an evaporative climate indicates that snow-packsourced ground-water discharge remained high during warm evaporative summers. Bear Lake hydrology combined with evaporation created an unusual situation that produced large amounts of aragonite, but no evaporite minerals (e.g., gypsum and halite). The thick sedimentary package in the lake also argues for relative stability. Acoustic reflection profiles show that the deepest part of the lake contains at least several hundred meters of sediment that might be as much as six million years old (Colman, 2005). A 120-m-long core was collected from the deepest part of the lake with the GLAD800 system in 2000 (BL00-1, Fig. 2; Dean et al., 2002a). The dominant carbonate mineral in this core is calcite, but aragonite occurs in sediments deposited during the last two interglacial intervals (marine oxygen isotope stages 5 and 7; Dean, 2005; Bright et al., in press).

The key variable for aragonite formation appears to be a high $\mathrm{Mg}: \mathrm{Ca}$ ratio (Müller et al., 1972), and an increase in $\mathrm{Mg}$ :Ca ratio usually is accompanied by an increase in salinity (Kelts and Hsü, 1978). According to the model of Harvie and Weare (1980) the predicted sequence of carbonate minerals formed with increasing $\mathrm{Mg}$ :Ca ratio should be low-Mg calcite $(<5 \mathrm{~mol} \% \mathrm{Mg})$, high-Mg calcite $(>10 \mathrm{~mol} \% \mathrm{Mg})$, and then aragonite. Müller et al. (1972) suggested that low-Mg calcite forms in lakes with a $\mathrm{Mg}$ :Ca ratio $<2$, high- $\mathrm{Mg}$ calcite forms in lakes with a $\mathrm{Mg}$ :Ca ratio of 2-12, and aragonite only precipitates in lakes with a $\mathrm{Mg}: \mathrm{Ca}$ ratio $>12$. The presence of dissolved $\mathrm{Mg}$ strongly inhibits the precipitation of calcite and favors the precipitation of aragonite (e.g., Bischoff and Fyfe, 1968; Berner, 1975).
The diversion of Bear River into Bear Lake at the beginning of the 20th century changed the chemistry of Bear Lake and created an experiment in carbonate chemistry that is reflected in carbonate minerals in the sediments (Dean et al., 2005). Today, the total dissolved solids (TDS) content and the $\mathrm{Mg}$ :Ca ratio (in $\mathrm{mg} / \mathrm{L}$ ) are about 500 and 1.7:1 (Dean et al., 2005), and the lake is precipitating high-Mg calcite. The TDS content and $\mathrm{Mg}: \mathrm{Ca}$ ratio in a sample of Bear Lake water collected about the time of diversion in 1912 were 1100 and 37:1 (Kemmerer et al., 1923). Thus, at about the time of Bear River diversion, the salinity of Bear Lake was about twice that of today, but the $\mathrm{Mg}$ :Ca ratio was more than 20 times higher. Therefore, prior to diversion aragonite was the preferred polymorph of $\mathrm{CaCO}_{3}$.

Because the more open crystal lattice of aragonite can more readily accommodate substitution of larger $\mathrm{Sr}^{2+}$ and $\mathrm{Ba}^{2+}$ ions for the smaller $\mathrm{Ca}^{2+}$ ions than the less open lattice of calcite (Morse and Mackenzie, 1990), Ba and $\mathrm{Sr}$ concentrations and the $\mathrm{Sr}: \mathrm{Ca}$ ratio in the leachate also increased with aragonite precipitation (Fig. 11). The $\mathrm{Mg}^{2+}$ ion is smaller than the $\mathrm{Ca}^{2+}$ ion and can easily substitute for $\mathrm{Ca}^{2+}$ in the calcite lattice. Calcite in Bear Lake sediments usually contains more $\mathrm{Mg}$ than aragonite (Fig. 11), but that also depends on the $\mathrm{Mg}: \mathrm{Ca}$ ratio of the water. The three-fold increase in $\mathrm{Mg}$ in aragonite over the last 4000 years, to values that are as high or higher than those in calcite deposited between 17 and $11 \mathrm{cal} \mathrm{ka} \mathrm{(Fig.} \mathrm{11),} \mathrm{probably} \mathrm{is} \mathrm{due} \mathrm{to} \mathrm{a}$ three-fold increase in the $\mathrm{Mg}$ :Ca ratio in the late Holocene lake (Fig. 11). The $\mathrm{Mn}^{2+}$ ion also is smaller than the $\mathrm{Ca}^{2+}$ ion and can easily explain the higher $\mathrm{Mn}$ content in calcite than in aragonite (Fig. 11). Manganese carbonates (in fact all transition-element carbonates) are isostructural with calcite, whereas strontium carbonate is isostructural with aragonite (Morse and Mackenzie, 1990).

By $10 \mathrm{cal} \mathrm{ka}$, values of $\delta^{18} \mathrm{O}$ had increased by $6 \%$ o from $-11 \%$ to $-5 \%$, and values of $\delta^{13} \mathrm{C}$ had increased from $-1 \%$ o to $+2.5 \%$ o. Ratios of ${ }^{87} \mathrm{Sr} /{ }^{86} \mathrm{Sr}$ also increased during this interval (12 to $10 \mathrm{cal} \mathrm{ka;} \mathrm{Fig.} \mathrm{9).}$ At that time $(10 \mathrm{cal} \mathrm{ka})$, the mineralogy and isotopic composition of bulk carbonate had approached values that would be typical of most of the Holocene (Figs. 5 and 9). A salinity increase, indicated by the higher aragonite concentrations, was accompanied by a drop in lake level by more than $25 \mathrm{~m}$ below modern level (Smoot and Rosenbaum, 2005). The marked increases in values of both $\delta^{18} \mathrm{O}$ and $\delta^{13} \mathrm{C}$ (Fig. 9) and a distinct isotopic covariance in carbonates deposited after 12 cal ka (Fig. 10A) indicate increased residence time of the lake (Talbot, 1990). 
Just after 9.5 cal ka, values of ${ }^{87} \mathrm{Sr} /{ }^{86} \mathrm{Sr}$ begin to decrease indicating that Bear River water was entering Bear Lake, and by $9.0 \mathrm{cal}$ ka decreasing values of $\delta^{18} \mathrm{O}$ show that the lake freshened rapidly (Fig. 9). Because the $\mathrm{Sr}$ concentration in the lake was so low, the effect of change on the isotopic composition of $\mathrm{Sr}$ would have been felt immediately, but it took a while longer for the change to be felt in the much larger oxygen-isotope system. During this freshening episode, the $\mathrm{Mg} / \mathrm{Ca}$ ratio became smaller, but it did not become low enough for the mineralogy to shift from aragonite to calcite until after $8.5 \mathrm{cal} \mathrm{ka}$ (Fig. 5). This change in mineralogy is reflected in the $\mathrm{HCl}$-leach chemistry by increases in $\mathrm{Mg}$ and $\mathrm{Mn}$ and decreases in $\mathrm{Sr}$ and $\mathrm{Ba}$ (Fig. 11). At about $8 \mathrm{cal} \mathrm{ka}$, values of ${ }^{87} \mathrm{Sr} /{ }^{86} \mathrm{Sr}$ began to increase indicating that Bear Lake was beginning to detach from Bear River (Fig. 9). This detachment was not felt by the carbon and oxygen isotopes until about $7.5 \mathrm{cal} \mathrm{ka}$, and by that time calcite was rapidly being replaced by aragonite.

The cause of the brief reconnection of Bear River with Bear Lake may have been tectonic, geomorphic, or climatic. Evidence from Elk Lake, Minnesota, suggests that the polar front in summer was south of northern Minnesota prior to about $8.3 \mathrm{cal} \mathrm{ka}$, and was displaced northward at about $8.2 \mathrm{ka}$, permitting the introduction of strong westerly winds (Dean et al., 2002b). Although the displacement of the polar front and beginning of westerlies was at $8.2 \mathrm{cal} \mathrm{ka}$, there was about a 500-year period centered on $9.5 \mathrm{cal} \mathrm{ka}$ when there is evidence (increased varve thickness and quartz content) that winds began to increase, but then the winds decreased, and the period between 9.2 and $8.2 \mathrm{cal}$ ka contains some of the thinnest varves in the Elk Lake record (Dean et al., 2002b). This 1000-year interval is when Cytherissa lacustris, a boreal ostracode, was most abundant. $C$. lacustris lives in cold lakes in the boreal forests of Canada and Alaska, and cannot tolerate physical and chemical environmental variability (Dean et al., 2002b). This atmospheric perturbation may have permitted the temporary establishment of a polar low over Utah, Idaho, and Wyoming in winter, increasing the snow pack in the Uinta Mountains, the headwaters of the Bear River. Such a climatic event also would have increased the snow pack in the Bear River Range to the west of the lake thereby increasing the surface- and ground-water flow to the west side of the lake. The interpretation, then, is that when $C$. lacustris was at its greatest abundance in Elk Lake indicating the southernmost extent of the polar front in the early Holocene, increased snow melt in the Uinta Mountains and the Bear River Range increased the influx of surface and ground water into Bear Lake between 9.2 and $8.2 \mathrm{cal} \mathrm{ka}$ (decrease in ${ }^{87} \mathrm{Sr} /{ }^{86} \mathrm{Sr}$ ). This resulted in a rise in lake level of about $10 \mathrm{~m}$ above modern level (Smoot and Rosenbaum, 2005). At $8.2 \mathrm{cal} \mathrm{ka}$ the abundance of $C$. lacustris in Elk Lake was greatly reduced indicating that the polar front had moved north and was replaced by the prairie ostracodes Candona rawsoni and Limnocythere herricki, marking the beginning of the altithermal or prairie period in Minnesota (Dean et al., 2002b). At that time, surface- and ground-water influx to Bear Lake decreased and the salinity of the lake began to increase (increase in ${ }^{87} \mathrm{Sr} /{ }^{86} \mathrm{Sr}$ ).

The increase in supply of water to Bear Lake, whatever its source, and associated lake-level rise probably corresponds to the Willis Ranch shoreline (Laabs and Kaufman, 2003). This shoreline is at an elevation of about 1814 masl ( $8 \mathrm{~m}$ above modern lake level) indicating that at that time Bear Lake occupied most of the Bear Lake Valley. The Willis Ranch shoreline was calibrated at 9.2 cal ka (Laabs and Kaufman, 2003), but this date is based on a conventional ${ }^{14} \mathrm{C}$ analysis of a large collection of shells $\left(8.27{ }^{14} \mathrm{C} \mathrm{ka}\right.$; Williams et al., 1962 ) and is probably too old, as suggested by the reservoir effect of 370 years used by Colman et al. (2005) to correct ostracode ages. With the reentry of Bear River, there is no increase in quartz (Fig. 5) to indicate that Bear River sediment also was entering the lake, so the sediment must have been trapped. Topographically, the most obvious place for Bear River to enter the lake is at the north end where it enters today through man-made canals. Perhaps by that time a marsh-lake complex, today represented by Dingle Marsh and Mud Lake (Fig. 1), had developed at the north end of the lake trapping Bear River sediment.

The lower salinity event lasted about 1000 years, and by $7.5 \mathrm{cal} \mathrm{ka}$ aragonite was again forming and values of $\delta^{18} \mathrm{O}$ and $\delta^{13} \mathrm{C}$ of carbonate were increasing. The mineralogy of carbonate in Bear Lake sediments has been relatively constant for the last $7 \mathrm{ky}$ (Fig. 5), but values of $\delta^{18} \mathrm{O}, \delta^{13} \mathrm{C}$, and ${ }^{87} \mathrm{Sr} /{ }^{86} \mathrm{Sr}$ continued to increase slightly (Fig. 9), indicating that perhaps salinity continued to increase after Bear River was again disconnected from Bear Lake at $7 \mathrm{cal} \mathrm{ka}$, and evaporation dominated over precipitation. However, Bear Lake waters never reached highly evolved values of $\delta^{18} \mathrm{O}(>0 \%)$ in spite of an evaporation-dominated water balance.

\section{Conclusions}

A composite section from three piston cores from 30 to $50 \mathrm{~m}$ water depth, each up to $5 \mathrm{~m}$ long, was used to reconstruct the history of the Bear Lake for the last 31,000 years. This composite section reveals the com- 
ing and going of the Bear River, and a complex carbonate mineralogy involving aragonite, low-Mg calcite, and dolomite.

During the last glacial interval, increased Pacific moisture that filled the large lake basins of the Great Basin region, provided sufficient glaciation, snow pack, and snow melt in the Uinta Mountains and the Bear River Range to connect Bear Lake with Bear River. Sediments deposited during the last glacial interval consist of detrital quartz and feldspar transported by the Bear River, with minor amounts of low-Mg calcite and dolomite. The quartz and feldspar are detrital, and most, if not all, of the low-Mg calcite and dolomite also are probably detrital, derived mainly from Paleozoic carbonate rocks in the Bear River Range to the west of the lake.

Between 18 and 16 cal ka, Bear River abandoned Bear Lake and endogenic carbonate, first as calcite, began to precipitate as air temperature increased, evaporation exceeded freshwater influx, and the salinity of the lake increased. The oxygen and carbon isotopic ratios and organic carbon content of the endogenic carbonate show that after 16 ka the salinity continued to increase, the water became warmer, and organic productivity increased. Because of this combination of environmental events, a threshold was reached at about $11 \mathrm{cal} \mathrm{ka}$ when carbonate mineralogy abruptly changed from calcite to aragonite. Aragonite formation in a large, deep, montane lake is highly unusual. The production of large quantities of aragonite under an evaporative climate indicates that ground-water discharge remained high during warm evaporative summers. Bear Lake hydrology combined with evaporation created an unusual situation that produced large amounts of aragonite, but no evaporite minerals.

Aragonite precipitation dominated the sediments for about $2 \mathrm{ky}$, then, just as abruptly, returned to calcite precipitation for another $1 \mathrm{ky}$, between $8.5 \mathrm{cal} \mathrm{ka}$ and $7.5 \mathrm{cal} \mathrm{ka}$. This change in carbonate deposition probably was caused by reentry of the Bear River into Bear Lake, as suggested by more depleted oxygen, carbon, and strontium isotopic ratios.

By 7 cal ka, aragonite again dominated the sediments. This mode of carbonate sedimentation continued for the rest of the Holocene. Although the amount of aragonite did not increase during the last $7 \mathrm{ky}$, isotopic ratios of oxygen, carbon, and strontium continued to increase indicating that salinity continued to increase.

\section{Acknowledgments}

The 1996 Kullenberg piston cores were skillfully collected by Dawn Graber, Kerry Kelts, and Bob
Thompson. This and other studies at Bear Lake have benefited enormously from discussions with Darrell Kaufman and Jordon Bright. This research was supported through the USGS Earth Surface Dynamics Program. We thank Janet Pitman, Joe Smoot, Ana AlonsoZarza, and one anonymous reviewer for reviews of various versions of this paper.

\section{References}

Allen, B.D., Anderson, R.Y., 1993. Evidence from western North America for rapid shifts in climate during the last glacial maximum. Science 260, 1960-1923.

Allen, B.D., Anderson, R.Y., 2000. A continuous, high-resolution record of late Pleistocene climate variability from Estancia Basin, New Mexico. Geol. Soc. Am. Bull. 112, 1444-1458.

Anderson, R.Y, Allen, B.D., Menking, K.M., 2002. Geomorphic expression of abrupt climate change in southwestern North America at the glacial termination. Quat. Res. 57, 371-381.

Ashby, J.M., Geissman, J.W., Weil, A.B., 2001. Paleomagnetic results from the Neoproterozoic Uinta Mountain Group, Uinta Mountains, Northeastern Utah (abs). Geol. Soc. Am., Rocky Mountain (53rd) and South-Central (35th) Sections, Joint Ann. Meet. April 29-May 2, 2001.

Barnowsky, C.W., Anderson, P.M., Bartlein, P.J., 1987. The northwestern U.S. during deglaciation; vegetational history and paleoclimatic implications. In: Ruddiman, W.F., Wright, H.E. (Eds.), North America and Adjacent Oceans During the Last Deglaciation, The Geology of North America, K-3: Geol. Soc. Am., pp. 289-321. Boulder, CO.

Benson, L., Thompson, R.S., 1987. The physical record of lakes in the Great Basin, in North America and adjacent oceans during the last deglaciation. In: Ruddiman, W.F., Wright, H.E. (Eds.), North America and Adjacent Oceans During the Last Deglaciation, The Geology of North America, v. K-3: Geol. Soc. Am., pp. 241-260. Boulder, CO.

Berner, R.A., 1975. The role of magnesium in the crystal growth of calcite and aragonite from sea water. Geochim. Cosmochim. Acta 39, 489-504.

Birdsey, P.W., 1989. The Limnology of Bear Lake, Utah-Idaho, 1912-1988 A Literature Review. Publication No. 89-5. Utah Dept. Nat. Res., Div. Wildlife Res. 113 pp.

Bischoff, J.L., Fyfe, W.S., 1968. Catalysis, inhibition, and the aragonite-calcite problem: I. The aragonite-calcite transformation. Am. J. Sci. 266, 65-79.

Bischoff, J.L., Simmons, K., Shamp, D.D., 2005. Geochemistry of sediments in Bear Lake cores and sediment traps. U.S. Geol. Survey, Open-File Report 2005-1215. http://pubs.usgs.gov/of/ 2005/1215.

Bouchard, D.P., Kaufman, D.S., Hochberg, A., Quade, J., 1998. Quaternary history of the Thatcher Basin, Idaho, reconstructed from the ${ }^{87} \mathrm{Sr} /{ }^{86} \mathrm{Sr}$ and amino acid composition of lacustrine fossils: implications for the diversion of the Bear River into the Bonneville Basin. Palaeogeogr. Palaeoclimatol. Palaeoecol. 141, 95-114.

Bradbury, J.P., Forester, R.M., 2002. Environment and paleolimnology of Owens Lake, California: a record of climate and hydrology for the last 50,000 years. In: Hershler, R., Madsen, D.B., Currey, D.R. (Eds.), Great Basin Aquatic Systems History, Smithsonian Contributions to the Earth Sci. vol. 33. Smithsonian Institution Press, Washington, pp. 145-173. 
Bright, J., Kaufman, D.S., Forester, R.M., and Dean, W.E., in press. A continuous 250,000 yr record of oxygen and carbon isotopes in ostracode and bulk-sediment carbonate from Bear Lake, UtahIdaho. Quat. Sci. Rev.

Burton, E.A., Walter, L.M., 1987. Relative precipitation rates of aragonite and $\mathrm{Mg}$ calcite from seawater: temperature or carbonate ion control? Geology 15, 111-114.

Chave, K., 1954. Aspects of the biogeochemistry of magnesium: 1. Calcareous marine organisms. J. Geol. 62, 266-283.

COHMAP (Cooperative Holocene Mapping Project) Members, 1988. Climatic changes of the last 18,000 years: observations and model simulations. Science 241, 1043-1052.

Colman, S.M., 2005. Acoustic stratigraphy of Bear Lake, UtahIdaho-Late quaternary sedimentation in a simple half-graben. Sed. Geol. 185, 113-125.

Colman, S.M., Kaufman, D., Rosenbaum, J.G., and McGeehin, J,P., 2005. Radiocarbon dating of cores collected in Bear Lake, Utah. U.S. Geol. Survey, Open-File Report 2005-1288. http://pubs. usgs.gov/of/2005/1288.

Currey, D.R., 1990. Quaternary paleolakes in the evolution of semidesert basins, with special emphasis on Lake Bonneville and the Great Basin, U.S.A. Palaeogeogr. Palaeoclimatol. Palaeoecol. 76, $189-214$.

Dean, W.E., 1981. Carbonate minerals and organic matter in sediments of modern north temperate hard-water lakes. In: Ethridge, F., Flores, R. (Eds.), Recent and Ancient Nonmarine Depositional Environments: Models for Exploration, Soc. Econ. Mineralog. Paleontol., Sp. Publ. vol. 32, pp. 213-231. Tulsa, OK.

Dean, W.E., 2005. History of sedimentation in Bear Lake, UtahIdaho, over the last 250,000 years: links to Pacific climate (abs.). Geol. Soc. Am. 37, 336. (Abstracts with Programs).

Dean, W., Rosenbaum, J., Haskell, B., Kelts, K., Schnurrenberger, D., Valero-Garcés, B., Cohen, A. Davis, O., Dinter, D., Nielson, D., 2002a. Progress in Global Lake Drilling holds potential for Global Change research: EOS (Trans. Am. Geophys. Union), 83, $85,90,91$.

Dean, W.E., Forester, R.M., Bradbury, J.P., 2002b. Early Holocene change in atmospheric circulation in the Northern Great Plains: an upstream view of the $8.2 \mathrm{ka}$ cold event. Quat. Sci. Rev. 21, $1763-1775$.

Dean, W., Forester, R., Colman, S., Liu, A., Skipp, G., Simmons, K., Swarzinski, P., Anderson, R., 2005. Modern and glacial-Holocene carbonate sedimentation in Bear Lake, Utah-Idaho. U.S. Geol. Survey, Open-File Report 2005-11.24. http://pubs.usgs.gov/of/ 2005/1124.

Engleman, E.E., Jackson, L.L., Norton, D.R., Fischer, A.G., 1985. Determination of carbonate carbon in geological materials by coulometric titration. Chem. Geol. 53, 125-128.

Enzel, Y., Wells, S.G., Lancaster, N., 2003. Late Pleistocene lakes along the Mojave River, southeast California. In: Enzel, Y., Wells, S.G., Lancaster, N. (Eds.), Paleoenvironments and Paleohydrology of the Mojave and Southern Great Basin Deserts, Geol. Soc. Am. Sp. Paper vol. 368, pp. 61-77. Boulder, CO.

Harvie, C.E., Weare, J.H., 1980. The prediction of mineral solubilities in natural waters; the $\mathrm{Na}-\mathrm{K}-\mathrm{Mg}-\mathrm{Ca}-\mathrm{Cl}-\mathrm{SO}_{4}-\mathrm{H}_{2} \mathrm{O}$ system from zero to high concentrations at $25^{\circ} \mathrm{C}$. Geochim. Cosmochim. Acta 44, 981-998.

Hostetler, S.W., Giorgi, F., Bates, G.T., Bartlein, P.J., 1994. Lakeatmosphere feedbacks associated with paleolakes Bonneville and Lahontan. Science 263, 665-668.

Jackson, S.T., Betancourt, J.L., Lyford, M.E., Gray, S.T., Aasen Rylander, K., in press. A 40,000-year woodrat-midden record of vegetational and biogeographical dynamics in north-eastern Utah: J. Biogeog.

Kelts, K., Hsü, K.J., 1978. Freshwater carbonate sedimentation. In: Lerman, A. (Ed.), Lakes: Chemistry, Geology, Physics. SpringerVerlag, pp. 295-324.

Kemmerer, G., Bovard, J.F., Boorman, W.R., 1923. Northwestern lakes of the United states; biological and chemical studies with reference to possibilities to production of fish. U.S. Bur. Fish. Bull. 39, 51-140.

King, J.W., Channel, J.E.T., 1991. Sedimentary magnetism, environmental magnetism, and magnetostratigraphy. Rev. Geophys., Suppl., 358-370.

Kutzbach, J.E., 1987. Model simulations of the climatic patterns during the deglaciation of North America. In: Ruddiman, W.F., Wright, H.E. (Eds.), North America and Adjacent Oceans During the Last Deglaciation, The Geology of North America, K-3: Geol. Soc. Am., pp. 425-446. Boulder, CO.

Kutzbach, J.E., Guetter, P.J., Behling, P.J., Selin, R., 1993. Simulated climatic changes: results of the COHMAP climatic-model experiments. In: Wright Jr., H.E., Kutzbach, J.E., Webb III, T., Street-Perrott, F.A., Bartlein, P.J. (Eds.), Global Climates Since the Last Glacial Maximum. Univ. Minn. Press, Minneapolis, pp. 24-93.

Laabs, B.J.C., Kaufman, D.S., 2003. Quaternary highstands in Bear Lake valley, Utah and Idaho. Geol. Soc. Am. Bull. 115, 463-478.

Lowenstam, H.A., 1954. Factors affecting the aragonite:calcite ratios in carbonate-secreting marine organisms. J. Geol. 62, 284-322.

Markgraf, V., Bradbury, J.P., Forester, R.M., Singh, G., Sternberg, R.S., 1984. San Agustin Plains, New Mexico: age and paleoenvironmental potential reassessed. Quat. Res. 22, 336-343.

McKenzie, J.A., 1985. Carbon isotopes and productivity in the lacustrine and marine environment. In: Stumm, W. (Ed.), Chemical Processes in Lakes. Wiley, New York, pp. 99-118.

Moore, D.M., Reynolds Jr., R.C., 1989. X-ray Diffraction and Identification and Analysis of Clay Minerals. Oxford University Press. $332 \mathrm{pp}$.

Morse, J.W., Mackenzie, F.T., 1990. Developments in sedimentology. Geochemistry of Sedimentary Carbonates vol. 48. Elsevier, pp. 707.

Müller, G., Irion, G., Forstner, U., 1972. Formation and diagenesis of inorganic $\mathrm{Ca}-\mathrm{Mg}$ carbonates in the lacustrine environment. Naturwissen $59,158-164$.

Munroe, J.S., 2003. Holocene timberline and palaeoclimate of the northern Uinta Mountains, northeastern Utah, USA. Holocene 13, $175-185$.

Oviatt, C.D., 1997. Lake Bonneville fluctuations and global climate change. Geology 25, 155-158.

Oviatt, C.G., Currey, D.R., Sack, D., 1992. Radiocarbon chronology of Lake Bonneville, eastern Great Basin, USA. Palaeogeogr. Palaeoclimatol. Palaeoecol. 99, 225-241.

Quade, J., Forester, R.M., Whelan, J.F., 2003. Late Quaternary paleohydrologic and paleotemperature change in southern Nevada. In: Enzel, Y., Wells, S.G., Lancaster, N. (Eds.), Paleoenvironments and Paleohydrology of the Mojave and Southern Great Basin Deserts, Geol. Soc. Am. Sp. Paper vol. 368, pp. 165-188. Boulder, CO.

Rosenbaum, J.G., 2005. The glacial/deglacial history of sedimentation in Bear Lake (Utah and Idaho) (abs.). Geol. Soc. Am. 37, 336 (Abstracts with Programs).

Smoot, J.P., 2005, Sedimentary features of cores BL96-1, -2, and -3 from Bear Lake, Utah and Idaho. U.S. Geol. Survey Open-File Report 2005-1205. http://pubs.usgs.gov/of/2005/1205. 
Smoot, J.P., Rosenbaum, J.G., 2005. Sedimentary constraints on the magnitude of Holocene lake level change in Bear Lake, UtahIdaho (abs). Geol. Soc. Am. 37, 336 (Abstracts with Programs).

Talbot, M.R., 1990. A review of the palaeohydrological interpretation of carbon and oxygen isotopic ratios in primary lacustrine carbonates. Chem. Geol. (Isotope Geosci. Section) 80, 261-279.

Thompson, R.S., 1990. Late Quaternary vegetation and climate in the Great Basin. In: Betancourt, J.L., Van Devender, T.R., Martin, P.S. (Eds.), Packrat Middens-The Last 40,000 Years of Biotic Change. Univ. Ariz. Press, Tucson, pp. 200-239.

Thompson, R.S., Benson, L., Hattori, E.M., 1986. A revised chronology for the last Pleistocene lake cycle in the Lahontan Basin. Quat. Res. 25, 1-9.

Thompson, R.S., Whitlock, C., Bartlein, P.J., Harrison, S.P., Spaulding, W.G., 1993. Climatic changes in the western United States since 18,000 yr BP. In: Wright Jr., H.E., Kutzbach, J.E., Webb III,
T., Street-Perrott, F.A., Bartlein, P.J. (Eds.), Global Climates Since the Last Glacial Maximum. Univ. Minn. Press, Minneapolis, pp. $468-513$.

Wells, S.G., Brown, W.J., Enzel, Y., Anderson, R.Y., McFadden, L.D., 2003. Late Quaternary geology and paleohydrology of pluvial Lake Mojave, southern California. In: Enzel, Y., Wells, S.G., Lancaster, N. (Eds.), Paleoenvironments and Paleohydrology of the Mojave and Southern Great Basin Deserts, Geol. Soc. Am. Sp. Paper vol. 368, pp. 79-114. Boulder, CO.

Williams, J.S., Willard, A.D., Parker, V., 1962. Recent history of Bear Lake Valley, Utah-Idaho. Am. J. Sci. 260, 24-36.

Wurtsbaugh, W., Luecke, C., 1997. Examination of the abundance and spatial distribution of forage fish in Bear Lake (Utah/Idaho). Report of Project F-47-R, Study 5, to the Utah Div. Wildlife Res., pp. 217. Salt Lake City, Utah. 